\title{
Root Treatment with Rhizobacteria Antagonistic to Phytophthora Blight Affects Anthracnose Occurrence, Ripening, and Yield of Pepper Fruit in the Plastic House and Field
}

\author{
Mee Kyung Sang, Jeong Do Kim, Beom Seok Kim, and Ki Deok Kim
}

First and fourth authors: Laboratory of Plant Disease and Biocontrol, and second and third authors: Laboratory of Phytopharmacology, College of Life Sciences and Biotechnology, Korea, University, Seoul 136-713, Republic of Korea. Accepted for publication 22 January 2011.

\begin{abstract}
Sang, M. K., Kim, J. D., Kim, B. S., and Kim, K. D. 2011. Root treatment with rhizobacteria antagonistic to Phytophthora blight affects anthracnose occurrence, ripening, and yield of pepper fruit in the plastic house and field. Phytopathology 101:666-678.

We previously selected rhizobacterial strains CCR04, CCR80, GSE09, ISE13, and ISE14, which were antagonistic to Phytophthora blight of pepper. In this study, we investigated the effects of root treatment of rhizobacteria on anthracnose occurrence, ripening, and yield of pepper fruit in the plastic house and field in 2008 and 2009. We also examined the effects of volatiles produced by the strains on fruit ripening and on mycelial growth and spore development of Colletotrichum acutatum and Phytophthora capsici in the laboratory, identifying the volatile compounds by gas chromatography-mass spectrometry (GC-MS). In the house tests, all strains significantly $(P<0.05)$ reduced anthracnose incidence on pepper fruit; strains GSE09 and ISE14 consistently produced higher numbers of pepper fruit or increased the fresh weight of red fruit

increased fresh weights of red fruit more than the controls in both years. In the laboratory tests, volatiles produced by strains GSE09 and ISE13 only stimulated maturation of pepper fruit from green (unripe) to red (ripe) fruit; the volatiles of certain strains inhibited the growth and development of $C$. acutatum and P. capsici. On the other hand, GC-MS analysis of volatiles of strains GSE09 and ISE13 revealed 17 distinct compounds in both strains, including decane, dodecane, 1,3-di-tert-butylbenzene, tetradecane, 2,4-di-tert-butylphenol, and hexadecane. Among these compounds, 2,4-di-tert-butylphenol only stimulated fruit ripening and inhibited growth and development of the pathogens. Taken together, strains GSE09 and ISE14 effectively reduced anthracnose occurrence and stimulated pepper fruit ripening and yield, possibly via bacterial volatiles. Therefore, these two strains could be potential agents for controlling Phytophthora blight and anthracnose, and for increasing fruit ripening and yield. To our knowledge, this is the first report of volatiles such as 2,4-di-tert-butylphenol produced by rhizobacteria being related to both fruit ripening and pathogen inhibition.
\end{abstract} more than the controls in both years. In the field tests, all strains significantly $(P<0.05)$ reduced anthracnose occurrence on either green or red pepper fruit; strain ISE14 consistently produced higher numbers or
Additional keywords: induced systemic resistance.

nistic agent $(3,4)$. Induced systemic resistance (ISR) and plant growth promotion were reported to be related, with rhizobacterial volatiles in plants as prospective inducers $(10,46)$. These volatile compounds produced by antagonistic microorganisms affect the growth of fungal pathogens and disease development $(6,32)$. Fernando et al. (11) found that antifungal organic volatiles produced by Pseudomonas spp. significantly inhibited the sclerotium formation and mycelial growth of Sclerotinia sclerotiorum. Subsequently, they identified the volatile compounds as benzothiazole, cyclohexanol, $n$-decanal, dimethyl trisulfide, 2-ethyl 1-hexanol, and nonanal, in which benzothiazole was reported to play an important role in soil fungistasis (59). Soil fungistasis has been proposed to result from nutrient deprivation and antibiosis due to the physical and chemical properties of soils as well as soil microbial activity; this leads to suppression of fungal germination or growth in natural soils $(33,45)$.

In addition to biocontrol activity by volatile compounds, volatiles produced by antagonistic rhizobacteria or fungi could enhance plant growth $(32,47)$. Gutiérrez-Luna et al. (16) reported that plant growth-promoting rhizobacteria (PGPR) such as Bacillus cereus, B. simplex, and other Bacillus spp. enhanced plant growth and modulated root-system architecture in Arabidopsis thaliana through bacterial volatile compounds. In relation to plant growth promotion, it is well known that many antagonistic rhizobacteria themselves are capable of promoting plant growth along with biocontrol activity in various plants $(15,20)$. Treatment with PGPR bacilli strains was effective against Phytophthora

doi:10.1094/PHYTO-08-10-0224

(C) 2011 The American Phytopathological Society 
blight caused by P. capsici on squash (58), and three strains of PGPR such as Serratia sp., fluorescent pseudomonad, and Bacillus sp. were effective for the control of bacterial wilt of tomato caused by Ralstonia solanacearum in greenhouse and field tests (15).

In our previous study $(49,51)$, we selected several rhizobacterial strains antagonistic to Phytophthora blight of pepper using a sequential selection procedure from radical assays to field tests (22). Root treatment with the antagonistic strains effectively reduced the disease in pepper plants and frequently promoted the plant growth $(49,51)$; therefore, we conducted a preliminary test to evaluate the plant growth-promoting effects of these bacterial strains in a commercial plastic house without history of soilborne disease occurrence. From this test, we were able to observe that some of these strains reduced anthracnose on green or red pepper fruit and produced more red fruit near the soil line than untreated controls, which might indicate an association of bacterial volatiles released from the bacteria-treated soil. Therefore, in this study, we investigated (i) the effects of the antagonistic rhizobacteria on anthracnose occurrence and yield of green and red pepper fruit in the plastic house and field in 2008 and 2009 and (ii) the effects of volatiles produced by the antagonistic rhizobacteria not only on fruit ripening from green (unripe) to red (ripe) but also on mycelial growth and spore development of $C$. acutatum and $P$. capsici. In addition, we identified the volatile compounds of the rhizobacteria by gas chromatography-mass spectrometry (GCMS) and examined the biological activity of the identified compounds in fruit ripening and growth and development of the pathogens.

\section{MATERIALS AND METHODS}

Bacterial strains. Five bacterial strains-Pseudomonas corrugata strains CCR04 and CCR80, Flavobacterium sp. strain GSE09, Lysobacter enzymogenes strain ISE13, and Chryseobacterium indologenes strain ISE14-which are antagonistic to Phytophthora blight of pepper, were used in this study (49). For the preparation of bacterial suspensions, bacterial strains were incubated on nutrient agar (NA) (Difco Laboratories, Detroit) at $28^{\circ} \mathrm{C}$ for $48 \mathrm{~h}$. The single colonies were cultured in $5 \mathrm{ml}$ of nutrient broth (NB) (Difco Laboratories) in a shaking incubator $(160 \mathrm{rpm})$ at $28^{\circ} \mathrm{C}$ for $24 \mathrm{~h}$. These precultured strains were inoculated in $500 \mathrm{ml}$ of $\mathrm{NB}$ and incubated under the same conditions for $48 \mathrm{~h}$. Bacterial cells were harvested in $10 \mathrm{mM} \mathrm{MgSO}_{4}$ buffer by centrifuging at $5,000 \times g$ at $20^{\circ} \mathrm{C}$ for $15 \mathrm{~min}$, washed twice the same buffer, and then adjusted to $10^{8}$ bacterial cells $/ \mathrm{ml}$ (optical density at $600 \mathrm{~nm}=0.5$ ) with a spectrophotometer (Amersham Biosciences Ultrospec, Cambridge). These bacterial suspensions were used for plant treatments and bacterial volatile-efficacy experiments in this study.

Plastic house tests. Growth promotion and anthracnose suppression tests in pepper plants were conducted in a commercial, plastic (PE)-covered house (18 $\mathrm{m}$ wide by $45 \mathrm{~m}$ long) at Deokso Experiment Farm of Korea University, Namyangju, Korea in 2008 and 2009. Raised beds ( $20 \mathrm{~cm}$ high by $80 \mathrm{~cm}$ wide), spaced $1 \mathrm{~m}$ apart (center to center), were constructed and covered with black plastic mulch. Pepper plants ('Buchon') were grown for 10 weeks in 2008 and for 11 weeks in 2009 in 10-cm-diameter pots containing commercial potting mixture (Sunshine Mix Plug; Sun Gro Horticularue Canada Ltd., Seba Beach, Canada). Pepper plants were drenched once with $100 \mathrm{ml}$ of each bacterial strain suspension or $10 \mathrm{mM} \mathrm{MgSO}_{4}$ buffer (control) per pot on 19 April 2008 and 18 April 2009. These plants were transplanted into the beds in rows (45 cm between plants) on 22 April 2008 and 20 April 2009. Tests were established in beds with 3.6- and 4.5-mlong plots (two beds per treatment) and arranged in a randomized complete block with five and four replications per treatment in the 2008 and 2009 tests, respectively.
In the assessment of plant growth promotion by the bacterial strains, numbers and fresh weights of marketable pepper fruit (>8 cm long) were determined. Numbers of green (unripe) and red (ripe) fruit were counted twice on 2 and 25 August 2008 and on 29 July and 19 August in 2009 at 2 to 5 days before harvesting pepper fruit. The pepper fruit weights of red fruit only were determined twice after harvesting, on 4 and 27 August 2008 and 3 and 21 August 2009, for marketing purposes. To assess the effects of the bacterial strains against anthracnose on pepper fruit, naturally infected green and red fruit with distinct symptoms were simultaneously evaluated when fruit numbers were determined. Incidence (percent) of anthracnose on either green or red pepper fruit was determined as number of infected green or red fruit/total number of green or red fruit $\times 100$. Meanwhile, disease incidence (percent) of combined fruit was determined as number of total infected fruit/total number of fruit $\times 100$. Numbers and fresh weights (kilograms) of pepper fruit and anthracnose incidence were determined with five replications of 15 plants each in the 2008 test and four replications of 20 plants each in the 2009 test.

Field tests. Field tests similar to the plastic-house tests were conducted with the same bacterial strains at Deokso Experiment Farm of Korea University, Namyangju, Korea in 2008 and 2009. Raised beds ( $20 \mathrm{~cm}$ high by $60 \mathrm{~cm}$ wide), spaced $85 \mathrm{~cm}$ apart (center to center), were constructed as described above and pepper ('Nockwang') plants were grown for 13 weeks in 2008 and 11 weeks in 2009 in 50 -cell ( 5 by 5 by $6 \mathrm{~cm}$ ) plug trays filled with the same potting mixture as described above. Plant roots were dipped in the prepared bacterial suspensions or $10 \mathrm{mM}$ $\mathrm{MgSO}_{4}$ buffer (control) just before transplant into the beds. The root-dipped plants were transplanted into the beds in rows $(30 \mathrm{~cm}$ between plants) on 16 June 2008 and 14 May 2009. These tests were established in beds with 3.6- and 4.5-m-long plots (one bed per treatment) and arranged in a randomized complete block with four replications per treatment in the 2008 and 2009 tests, respectively.

In the assessment of plant growth promotion, numbers and weights of green and red pepper fruit were determined on 2 September 2008 and 5 August 2009 as described in the plastic-house tests. For determination of disease incidence (percent), naturally infected green and red fruit were evaluated just after harvesting pepper fruit as described above. Anthracnose incidence (percent) and numbers and fresh weights (kilograms) of green, red, and combined pepper fruit were determined with four replications of 7 plants each in the 2008 test and 10 plants each in the 2009 test.

Bacterial volatiles and fruit ripening. For evaluating pepper (Nockwang) fruit ripening by bacterial volatiles in the laboratory, healthy green (unripe) fruit ( $>8 \mathrm{~cm}$ long) were collected from plants grown in the field. Collected green fruit were dipped in $1 \%$ $\mathrm{NaOCl}$ solution for $5 \mathrm{~s}$, rinsed with sterile distilled water three times, blotted on sterile paper towels, and air dried in a hood. At the same time, $100 \mu \mathrm{l}$ of each bacterial suspension prepared as described above or of $10 \mathrm{mM} \mathrm{MgSO} 4$ buffer (control) were smeared on NA in plastic petri dishes (60 by $15 \mathrm{~mm}$ ) (SPL Life Sciences, Pocheon, Korea). These slightly surface-sterilized fruit and bacteria or buffer-smeared petri dishes were placed in plastic square plates (118.7 by 118.7 by $16.5 \mathrm{~mm}$ ) (SPL Life Sciences) at the same time, and then sealed with parafilm (Parafilm "M"; Pechiney Plastic Packaging, Chicago) as shown (Fig. 1A). These square plates were incubated at $28^{\circ} \mathrm{C}$ with fluorescent light at $16 \mathrm{~h} /$ day and percent color change from green (unripe) to red (ripe) fruit was assessed 8 and 10 days after incubation for experiments 1 and 2, respectively. Fruit ripening was also assessed based on a ripening index (0-to- 4 scale, where $0=$ green, $1=$ breaking, $2=<50 \%, 3=50$ to $89 \%$, and $4=\geq 90 \%$ red color of a fruit) (Fig. 1B). The experiments were conducted twice, with 10 replications each.

Isolation of anthracnose fungus. To assess the effects of bacterial volatiles against the anthracnose pathogen in the labora- 
tory, fungus was isolated from fruit of pepper (Nockwang) plants in the field at Deokso Experiment Farm of Korea University, Namyangju, Korea in 2008. Typical anthracnose lesions on green and red pepper fruit were surface-sterilized by $1 \% \mathrm{NaOCl}$ for $1 \mathrm{~min}$ and rinsed three times with sterile distilled water. The surface-sterilized fruit segments were placed on potato dextrose agar (PDA) (Difco Laboratories) amended with streptomycin $(50 \mu \mathrm{g} / \mathrm{ml})$ and incubated at $28^{\circ} \mathrm{C}$. The hyphal tips grown from the lesion segments were transferred to PDA and further incubated at the same temperature. After 5 days of incubation, two fungal isolates (isolate G4 from a green fruit and isolate R14 from a red fruit) (Fig. 2) among 14 and 31 isolates on green and red fruit, respectively, were observed frequently for their mycelial and conidial morphology on PDA. Therefore, these isolates were conducted for monoconidial isolation and used for further tests. The pathogenicity of these isolates was confirmed by drop inoculation (24) with $20 \mu \mathrm{l}$ of conidia suspensions $\left(5 \times 10^{5}\right.$ conidia/ml $)$ on green and red fruit of pepper ('Nockwang'), slightly surface scratched by sandpaper.

Molecular identification of anthracnose fungus. For identification of the fungal isolates G4 and R14, DNA was extracted from the isolates and purified based on the method of Freeman et al. (13). Amplification of $\beta$-tubulin gene was carried out by polymerase chain reaction (PCR) using the universal primers Bt2a-F (5'-GGT AAC CAA ATC GGT GCT GCT TTC-3') and Bt2b-R (5'-ACC CTC AGT GTA GTG ACC CTT GGC-3') (14). The PCR reactions were conducted in reaction mixtures with a final volume of $20 \mu \mathrm{l}$ containing $10 \mathrm{ng}$ of genomic DNA, $0.2 \mathrm{mM}$ dNTP, 10x reaction buffer, 1 unit of Taq DNA polymerase (iNtRON Biotechnology, Seoul, Korea), and $50 \mathrm{ng}$ of each oligonucleotide primer. Amplification reactions were conducted in a MyCycler thermal cycler (Bio-Rad, Hercules, CA) by subjecting the samples to the following conditions: denaturation for $5 \mathrm{~min}$ at $95^{\circ} \mathrm{C}$; followed by 35 cycles of $30 \mathrm{~s}$ at $95^{\circ} \mathrm{C}, 30 \mathrm{~s}$ at $60^{\circ} \mathrm{C}$, and $1 \mathrm{~min}$ at $72^{\circ} \mathrm{C}$; with a final extension at $72^{\circ} \mathrm{C}$ for $10 \mathrm{~min}$. PCR products were separated by electrophoresis on $1.5 \%$ agarose gels in $1 \times$ Tris-acetate-EDTA buffer at $100 \mathrm{~V}$ for $90 \mathrm{~min}$. The PCR products were purified using QIA quick PCR purification kits (Qiagen Inc., Chatsworth, CA) according to the manufacturer's instructions. The sequences of the $\beta$-tubulin gene from each fungal isolate were compared with those of Colletotrichum and Glomerella spp. using BLAST network services at the National Center for Biotechnology Information of the U.S. National Library of Medicine, Bethesda, MD. A phylogenetic tree was constructed with the neighbor-joining method using Molecular Evolutionary Genetics Analysis program (version 4.1; The Biodesign Institute, Tempe, AZ), and bootstrap analysis was conducted using the same program.

Bacterial volatiles and anthracnose fungus. To evaluate the effects of bacterial volatiles on growth and development of anthracnose fungus, 5-day-old mycelial plugs ( $5 \mathrm{~mm}$ in diameter) of isolates G4 and R14 were placed on PDA on one side of a plastic plate containing a center partition (I-plates; Fisher Scientific, Pittsburgh). Then, $100 \mu \mathrm{l}$ of each bacterial suspension prepared as described above or of $10 \mathrm{mM} \mathrm{MgSO}_{4}$ buffer (control) was smeared on NA on the other side of the plate. The I-plates were incubated at $28^{\circ} \mathrm{C}$; then, mycelial growth of the isolates was measured when mycelia almost reached the center partition of the I-plate treated with $10 \mathrm{mM} \mathrm{MgSO}_{4}$ buffer. On the other hand, to assess the effects of bacterial volatiles on fungal sporulation, conidial germination, and appressorium formation, conidia of the isolates grown on PDA in the I-plates were collected with $5 \mathrm{ml}$ of sterile distilled water. Conidial numbers were counted using a hemacytometer with a microscope and expressed as the number of conidia per square centimeter of fungal growth in the plates. For conidial germination and appressorium formation, the collected conidial suspensions $(20 \mu \mathrm{l})$ were dropped on glass slides in moisturized petri dishes. After incubation of the glass slides at $28^{\circ} \mathrm{C}$ for $24 \mathrm{~h}$, percent germination and appressorium formation were determined by observing $\approx 100$ conidia under a microscope. The experiments were conducted twice with four replications each.

Bacterial volatiles and Phytophthora blight pathogen. The effects of bacterial volatiles on mycelial growth, zoospore produc-

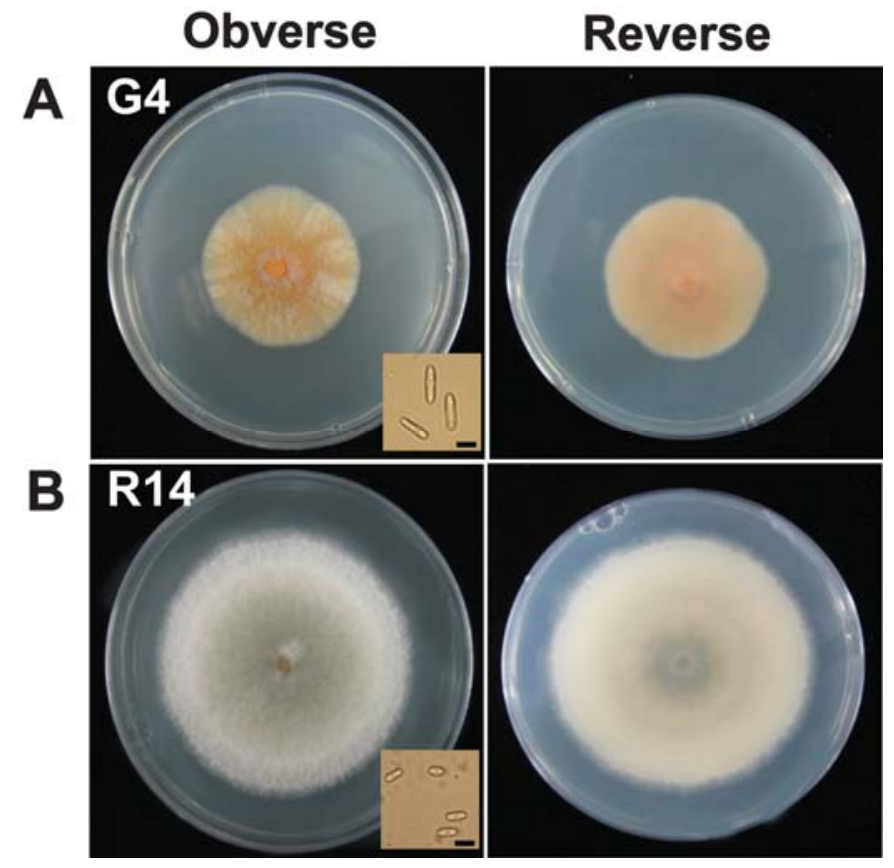

Fig. 2. Photographs of obverse and reverse mycelial morphology, and conidia (inset) of Colletotrichum acutatum isolates A, G4 and B, R14 7 days after inoculation on potato dextrose agar. $\mathrm{Bar}=5 \mu \mathrm{m}$.

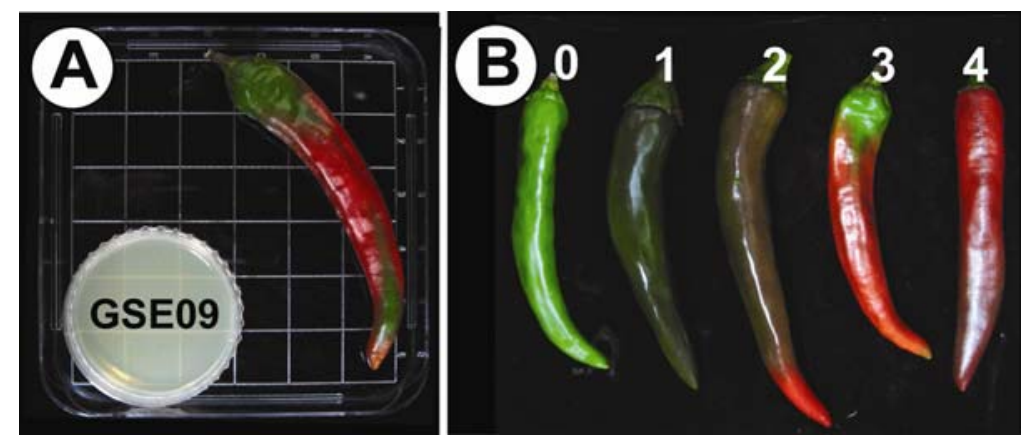

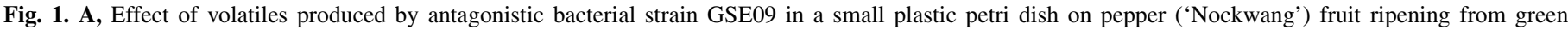

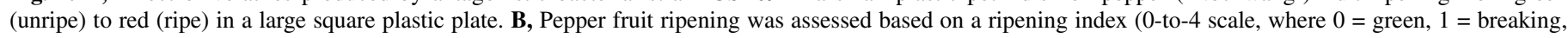
$2=<50 \%, 3=50$ to $89 \%$, and $4=\geq 90 \%$ red color of a fruit). 
tion, and germination of Phytophthora capsici isolate S197 were also examined. To evaluate mycelial growth, 5-day-old mycelial plugs ( $5 \mathrm{~mm}$ in diameter) of $P$. capsici were inoculated on V8 juice agar on one side of the I-plate, while each bacterial suspension prepared as described above or with $10 \mathrm{mM} \mathrm{\textrm {MSO } _ { 4 }}$ buffer (control) was smeared on NA on the other side of the plate. These I-plates were incubated at $28^{\circ} \mathrm{C}$; then, mycelial growth was measured as described for anthracnose fungus. To evaluate the zoospore production and germination, zoospores were prepared as described by Sang et al. (50); then, $400 \mu$ of the zoospore suspension $\left(10^{5}\right.$ zoospores $\left./ \mathrm{ml}\right)$ was smeared on V8 juice agar on one side of the I-plate. Three days after incubation at $28^{\circ} \mathrm{C}$, each bacterial suspension or $10 \mathrm{mM} \mathrm{MgSO}_{4}$ buffer was smeared on NA on the other side of the plate. These I-plates were incubated under continuous fluorescent light for 7 days at $28^{\circ} \mathrm{C}$ to induce zoosporangia. Then, $1 \mathrm{ml}$ of chilled sterile water was added to the cultures of $P$. capsici in the I-plates and the plates were placed at $4^{\circ} \mathrm{C}$ for $30 \mathrm{~min}$. Next, these plates were incubated at room temperature for $30 \mathrm{~min}$ to release the zoospores from zoosporangia. After vortexing the suspensions for $30 \mathrm{~s}$ to induce the zoospores to encyst, the number of zoospores was determined and expressed as described for anthracnose fungus; percent zoospore germination was also determined 2 to $4 \mathrm{~h}$ after incubation of treated glass slides at $28^{\circ} \mathrm{C}$ as described above. The experiments were conducted twice, with four replications each in mycelial growth tests and with three or four replications in zoospore production and germination tests in the repeated experiments.

GC-MS analysis of volatile compounds from strains GSE09 and ISE13. GC-MS analysis was conducted to identify volatile compounds from strains GSE09 and ISE13, both of which stimulate pepper fruit ripening and inhibit pathogen growth and development via emission of volatile chemicals. Strains GSE09 and ISE13 were grown on tryptic soy agar (TSA) and precultured in tryptic soy broth (TSB) as described for the bacterial preparation; these precultured strains were grown further in closed 1,000$\mathrm{ml}$ baffle flasks containing $100 \mathrm{ml}$ of TSB in a shaking incubator $(160 \mathrm{rpm})$ at $28^{\circ} \mathrm{C}$ for $24 \mathrm{~h}$. Uninoculated TSB was used as a control. Volatiles were then collected from the head space of the each flask containing the bacterial culture using a 50-ml gastight syringe (Hamilton Co., Reno, NV); $10 \mathrm{ml}$ of the collected volatiles was eluted in $500 \mu \mathrm{l}$ of hexane. This solution $(2 \mu \mathrm{l})$ was injected into a GC-MS system (Agilent 7890A for GC and 5975C MSD for MS; Agilent Technologies, Santa Clara, CA) equipped with a DB-5MS column ( $30 \mathrm{~m}$ by $0.25 \mathrm{~mm}$ by $0.25 \mu \mathrm{m})$ (Agilent Technologies) under the following conditions: injector, $200^{\circ} \mathrm{C}$; detector, $210^{\circ} \mathrm{C}$; and column oven, $30^{\circ} \mathrm{C}$ for $30 \mathrm{~min}$ with programming at a rate of $10^{\circ} \mathrm{C} / \mathrm{min}$ to $180^{\circ} \mathrm{C}$, then finally ramped at rate of $40^{\circ} \mathrm{C} / \mathrm{min}$ to $200^{\circ} \mathrm{C}$ for $2 \mathrm{~min}$. The carrier gas was $\mathrm{He}$ at

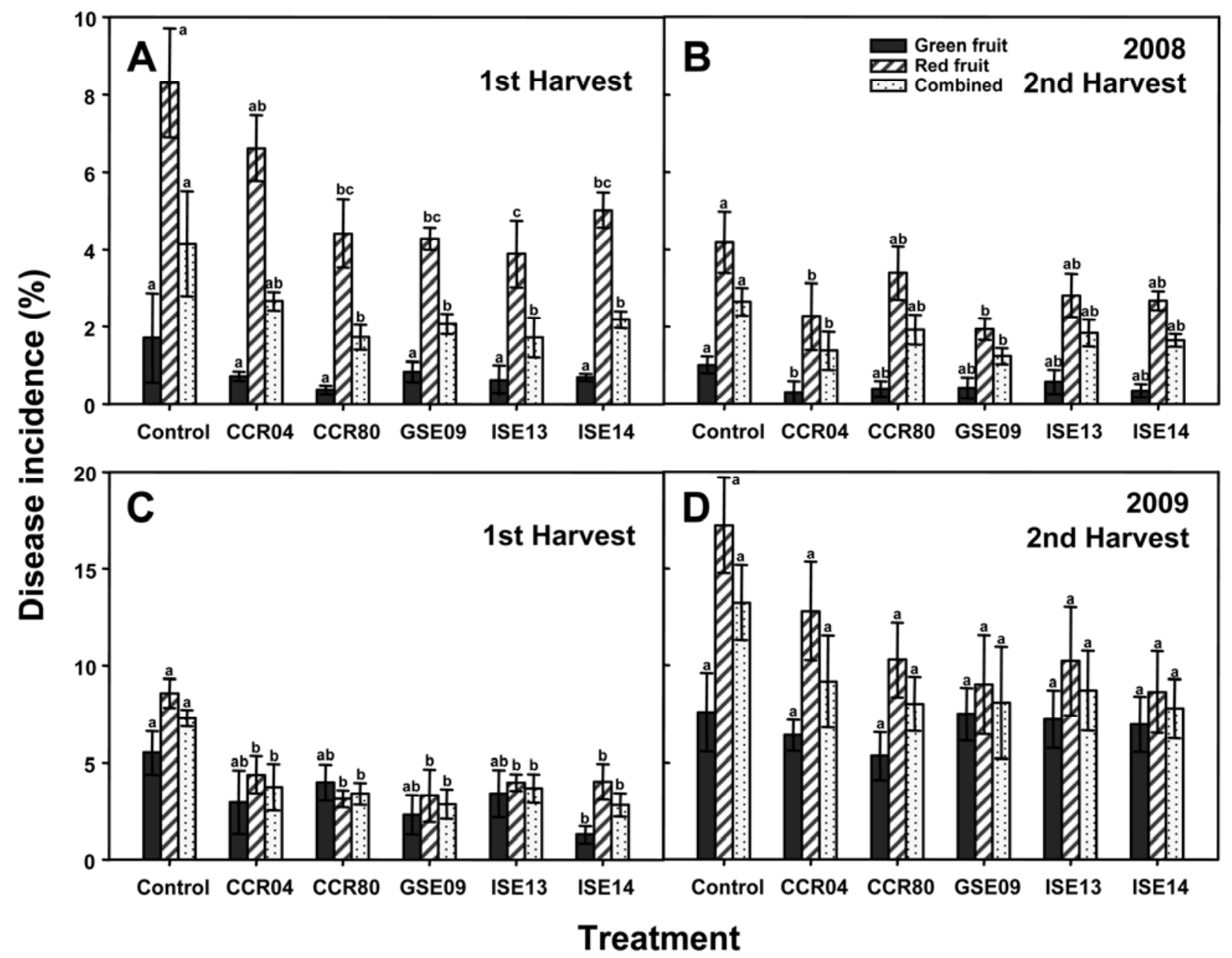

Fig. 3. Incidence (\%) of anthracnose on green and red fruit from pepper ('Buchon') plants after transplanting seedlings treated with the antagonistic bacterial strains CCR04, CCR80, GSE09, ISE13, and ISE14 or $10 \mathrm{mM} \mathrm{MgSO}_{4}$ buffer (control) at the time of harvesting fruit in the plastic house in 2008 and 2009 . Plants were treated once with $100 \mathrm{ml}$ of each bacterial suspension $\left(10^{8}\right.$ bacterial cells $\left./ \mathrm{ml}\right)$ or $10 \mathrm{mM} \mathrm{MgSO}_{4}$ buffer per plant on 19 April 2008 and 18 April 2009 . These plants were transplanted into the beds in rows on 22 April 2008 and 20 April 2009. Disease incidence was evaluated on 2 and 25 August 2008 and on 29 July and 19 August 2009. These experiments were conducted with five replications of 15 plants each in 2008 and four replications of 20 plants each in 2009 . Same letters on mean bars with standard errors are not significantly different between treatments for green, red, or combined fruit according to the least significant difference test at $P<0.05$. In disease incidence $(\%)$, arcsine square root-transformed data were used for statistical analysis; however, untransformed data are presented. 
a flow rate of $1 \mathrm{ml} / \mathrm{min}$. To confirm the tentatively identified compounds by GC-MS analysis, commercially available compounds were purchased from Sigma-Aldrich (St. Louis) and co-injected with the volatiles at the concentration of $0.2 \mathrm{ppm}$ to the GC-MS system. The experiments were conducted twice with three replicates each and produced similar results.

Biological activity of volatile compounds from strains GSE09 and ISE13. Based on the results of GC-MS analysis of the bacterial volatiles, the identified compounds, as well as strains GSE09 and ISE13, were tested for biological activity against pepper ('Nockwang') fruit ripening and pathogen growth and development. The identified compounds $(100 \mu \mathrm{g} / \mathrm{ml})$ were dissolved in sterile distilled water containing $2 \%$ ( $\mathrm{vol} / \mathrm{vol})$ dimethyl sulfoxide and $0.001 \%$ (vol/vol) Tween 20 for the use of this experiment. Sterile distilled water with dimethyl sulfoxide and Tween 20, as well as $10 \mathrm{mM} \mathrm{MgSO}_{4}$ buffer, were used as solvent and buffer controls, respectively. Based on the initial, repeated evaluations of the identified compounds against fruit ripening, growth, and development of Colletotrichum acutatum isolate R14, 2,4-di-tert-butylphenol was selected for further tests against fruit ripening, as well as $C$. acutatum isolates $\mathrm{G} 4$ and R14 and $P$. capsici isolate S197, due to its significant stimulation of fruit ripening and inhibition of isolate R14 (Supplemental Tables S1 and S2). The effects of the volatile compounds on fruit ripening and pathogen growth and development were assessed as described above. However, in this experiment, $5 \mathrm{ml}$ of each compound or solvent alone (solvent control) were applied to one side of the I-plate without medium while each bacterial suspension or $10 \mathrm{mM} \mathrm{MgSO}_{4}$ buffer (buffer control) was smeared on TSA medium on the same side of the plate. In addition, V8 juice agar amended with streptomycin $(50 \mu \mathrm{g} / \mathrm{ml})$ was used to evaluate the zoospore production of $P$. capsici. The experiments were conducted twice with 10 replicates each for the fruit-ripening test and four replicates each for the pathogen development tests.

Statistical analysis. Statistical analysis of data was conducted using the Statistical Analysis Systems (SAS Institute, Cary, NC). Data from repeated experiments in each test were pooled after confirming homogeneity of variances with Levene's test (29) and were further statistically analyzed. Percent data of disease incidence and fruit ripening as well as conidia and zoospore germination and appressorium formation were statistically analyzed after arcsine square-root transformation; the numbers of conidia

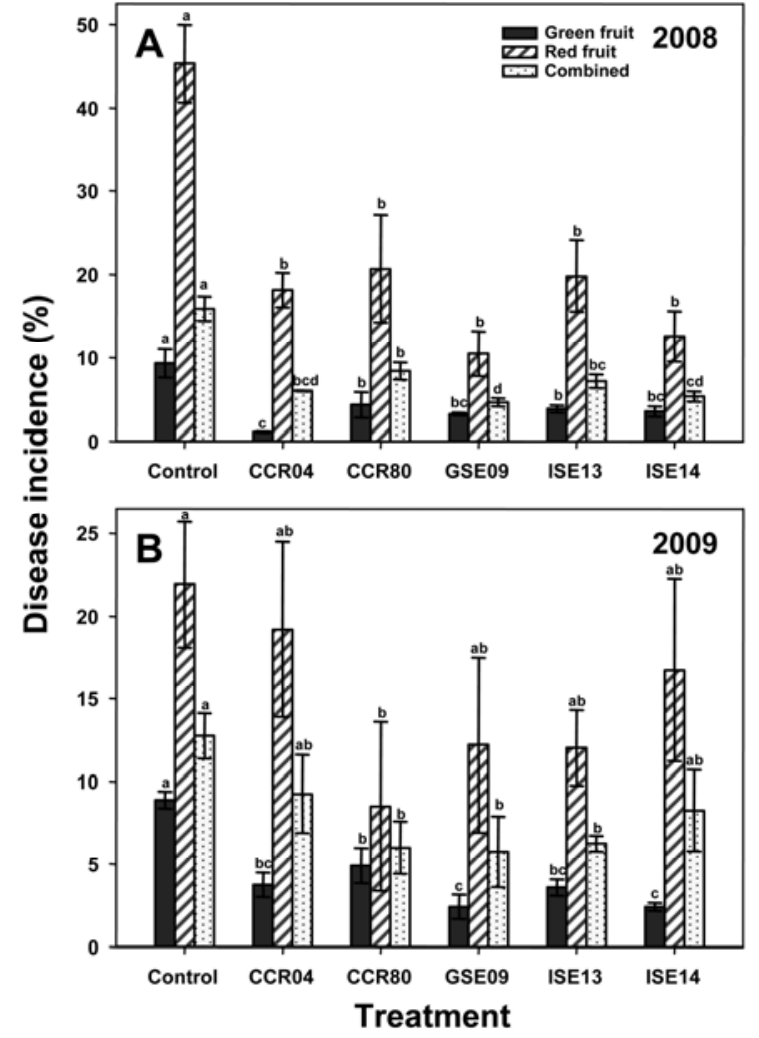

Fig. 4. Incidence (\%) of anthracnose on green and red fruit from pepper ('Nockwang') plants after transplanting seedlings treated with the antagonistic bacterial strains CCR04, CCR80, GSE09, ISE13, and ISE14 or $10 \mathrm{mM}$ $\mathrm{MgSO}_{4}$ buffer (control) in the field in 2008 and 2009. Pepper plants were treated once with $100 \mathrm{ml}$ of each bacterial suspension $\left(10^{8}\right.$ bacterial cells $\left./ \mathrm{ml}\right)$ or $10 \mathrm{mM} \mathrm{MgSO}_{4}$ buffer per plant on 13 June 2008 and 14 May 2009. These plants were transplanted into the beds in rows on 16 June 2008 and 14 May 2009. Disease incidence (\%) was evaluated on pepper fruit harvested on 2 September 2008 and 5 August 2009. These experiments were conducted with four replications of 7 and 10 plants each in 2008 and 2009, respectively. Same letters on mean bars with standard errors are not significantly different between treatments for green, red, or combined fruit according to the least significant difference test at $P<0.05$. In disease incidence $(\%)$, arcsine square root-transformed data were used for statistical analysis; however, untransformed data are presented.

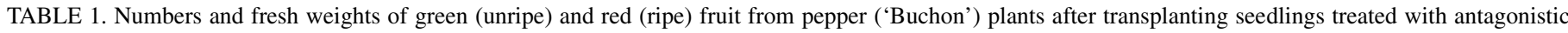
bacterial strains CCR04, CCR80, GSE09, ISE13, and ISE14 or $10 \mathrm{mM} \mathrm{MgSO}_{4}$ buffer (control) in the plastic house in 2008 and $2009{ }^{w}$

\begin{tabular}{|c|c|c|c|c|c|c|c|c|c|}
\hline \multirow{3}{*}{$\begin{array}{l}\text { Year, } \\
\text { treatment }^{\mathrm{x}}\end{array}$} & \multicolumn{6}{|c|}{ No. of pepper fruit ${ }^{\mathrm{y}}$} & & & \\
\hline & \multicolumn{3}{|c|}{ First harvest } & \multicolumn{3}{|c|}{ Second harvest } & \multicolumn{3}{|c|}{ Fresh weight of red pepper fruit $(\mathrm{kg})^{\mathrm{z}}$} \\
\hline & Green & Red & Combined & Green & Red & Combined & First harvest & Second harvest & Combined \\
\hline \multicolumn{10}{|l|}{2008} \\
\hline Control & $171.0 \pm 12.6 \mathrm{~b}$ & $302.3 \pm 22.3 b$ & $473.3 \pm 28.0 \mathrm{~b}$ & $234.5 \pm 19.7 \mathrm{c}$ & $223.0 \pm 14.2 \mathrm{a}$ & $457.5 \pm 32.1 \mathrm{~b}$ & $3.40 \pm 0.36 \mathrm{a}$ & $4.58 \pm 0.51 \mathrm{a}$ & $7.98 \pm 0.71 b$ \\
\hline CCR04 & $191.8 \pm 10.0 \mathrm{ab}$ & $408.8 \pm 13.6 \mathrm{a}$ & $600.5 \pm 14.8 \mathrm{a}$ & $263.0 \pm 10.8 \mathrm{bc}$ & $220.5 \pm 10.8 \mathrm{a}$ & $483.5 \pm 10.7 \mathrm{ab}$ & $3.66 \pm 0.21 \mathrm{a}$ & $5.23 \pm 0.18 \mathrm{a}$ & $8.88 \pm 0.29 \mathrm{ab}$ \\
\hline CCR80 & $194.3 \pm 17.8 \mathrm{ab}$ & $383.0 \pm 21.5 \mathrm{ab}$ & $577.3 \pm 34.9 \mathrm{ab}$ & $272.5 \pm 14.2 \mathrm{a}-\mathrm{c}$ & $238.8 \pm 19.5 \mathrm{a}$ & $511.3 \pm 29.1 \mathrm{ab}$ & $3.48 \pm 0.26 \mathrm{a}$ & $4.55 \pm 0.45 \mathrm{a}$ & $8.03 \pm 0.66 b$ \\
\hline GSE09 & $218.5 \pm 13.7 \mathrm{a}$ & $408.5 \pm 35.7 \mathrm{a}$ & $627.0 \pm 45.1 \mathrm{a}$ & $310.5 \pm 6.7 \mathrm{a}$ & $224.8 \pm 2.3 \mathrm{a}$ & $535.3 \pm 5.0 \mathrm{a}$ & $4.03 \pm 0.30 \mathrm{a}$ & $5.45 \pm 0.19 \mathrm{a}$ & $9.48 \pm 0.37 \mathrm{a}$ \\
\hline ISE13 & $204.0 \pm 11.7 \mathrm{ab}$ & $416.8 \pm 30.0 \mathrm{a}$ & $620.8 \pm 40.7 \mathrm{a}$ & $289.8 \pm 9.1 \mathrm{ab}$ & $206.0 \pm 16.1 \mathrm{a}$ & $495.8 \pm 24.2 \mathrm{ab}$ & $3.60 \pm 0.34 \mathrm{a}$ & $5.35 \pm 0.33 \mathrm{a}$ & $8.95 \pm 0.60 \mathrm{ab}$ \\
\hline ISE14 & $209.8 \pm 14.9 \mathrm{ab}$ & $407.5 \pm 15.5 \mathrm{a}$ & $617.3 \pm 12.8 \mathrm{a}$ & $295.8 \pm 18.6 \mathrm{ab}$ & $229.3 \pm 12.6 \mathrm{a}$ & $525.0 \pm 12.2 \mathrm{ab}$ & $4.05 \pm 0.35 \mathrm{a}$ & $4.83 \pm 0.11 \mathrm{a}$ & $8.88 \pm 0.27 \mathrm{ab}$ \\
\hline \multicolumn{10}{|l|}{2009} \\
\hline Control & $142.8 \pm 11.3 \mathrm{ab}$ & $209.8 \pm 4.8 \mathrm{a}$ & $352.5 \pm 15.6 \mathrm{ab}$ & $62.5 \pm 9.0 \mathrm{~b}$ & $88.0 \pm 13.9 \mathrm{c}$ & $150.5 \pm 20.2 \mathrm{c}$ & $2.93 \pm 0.40 b$ & $1.18 \pm 0.11 \mathrm{c}$ & $4.10 \pm 0.30 \mathrm{c}$ \\
\hline CCR04 & $134.0 \pm 22.4 \mathrm{~b}$ & $191.8 \pm 14.9 \mathrm{a}$ & $325.8 \pm 35.3 b$ & $86.3 \pm 18.8 \mathrm{ab}$ & $90.3 \pm 16.2 \mathrm{c}$ & $176.5 \pm 29.5 \mathrm{c}$ & $3.76 \pm 0.33 \mathrm{ab}$ & $1.67 \pm 0.26 \mathrm{bc}$ & $5.42 \pm 0.49 \mathrm{bc}$ \\
\hline CCR80 & $137.8 \pm 13.1 \mathrm{ab}$ & $223.3 \pm 20.7 \mathrm{a}$ & $361.0 \pm 28.4 \mathrm{ab}$ & $87.5 \pm 4.1 \mathrm{ab}$ & $98.8 \pm 3.3 \mathrm{bc}$ & $186.3 \pm 6.3 \mathrm{bc}$ & $3.53 \pm 0.33 \mathrm{ab}$ & $1.73 \pm 0.20 b c$ & $5.25 \pm 0.52 \mathrm{bc}$ \\
\hline GSE09 & $182.0 \pm 19.0 \mathrm{a}$ & $234.5 \pm 16.8 \mathrm{a}$ & $416.5 \pm 35.7 \mathrm{a}$ & $112.8 \pm 14.1 \mathrm{a}$ & $136.0 \pm 5.6 \mathrm{a}$ & $248.8 \pm 14.6 \mathrm{a}$ & $4.83 \pm 0.78 \mathrm{a}$ & $2.81 \pm 0.45 \mathrm{a}$ & $7.63 \pm 1.21 \mathrm{a}$ \\
\hline ISE13 & $179.5 \pm 16.3 \mathrm{ab}$ & $234.5 \pm 18.3 \mathrm{a}$ & $414.0 \pm 30.8 \mathrm{a}$ & $89.5 \pm 7.1 \mathrm{ab}$ & $94.3 \pm 16.1 \mathrm{bc}$ & $183.8 \pm 23.1 \mathrm{bc}$ & $4.08 \pm 0.53 \mathrm{ab}$ & $2.08 \pm 0.44 \mathrm{a}-\mathrm{c}$ & $6.16 \pm 0.91 \mathrm{a}-\mathrm{c}$ \\
\hline ISE14 & $158.0 \pm 4.8 \mathrm{ab}$ & $205.5 \pm 7.1 \mathrm{a}$ & $363.5 \pm 11.6 \mathrm{ab}$ & $116.8 \pm 15.8 \mathrm{a}$ & $125.5 \pm 6.0 \mathrm{ab}$ & $242.3 \pm 20.2 \mathrm{ab}$ & $3.86 \pm 0.40 \mathrm{ab}$ & $2.41 \pm 0.22 \mathrm{ab}$ & $6.28 \pm 0.58 \mathrm{ab}$ \\
\hline
\end{tabular}

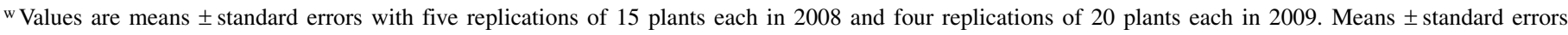
followed by the same letters are not significantly different between treatments according to the least significant difference test at $P<0.05$.

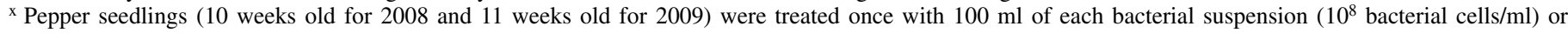
$10 \mathrm{mM} \mathrm{MgSO}$ buffer (control) per plant on 19 April 2008 and 18 April 2009. These seedlings were transplanted into the beds on 22 April 2008 and 20 April 2009.

y Numbers of marketable green and red fruit (>8 cm long) were counted twice on August 2 and 25 in 2008 and on July 29 and August 19 in 2009.

${ }^{z}$ Fresh weights of marketable red pepper fruit (>8 cm long) were determined twice after harvesting on 4 and 27 August 2008 and 3 and 21 August 2009. 
and zoospores were analyzed after log transformation. For analysis of ordinal data such as fruit ripening index, nonparametric analysis was used based on ranks of the data. In addition, correlation analysis was conducted to examine the relationship between the ripening index and the percent ripening color change using the transformed data. Multiple comparisons based on the least significant difference (LSD) test were also conducted to determine differences in mean ranks. Analysis of variance was determined using the general linear model procedures, and means were separated with the LSD test at $P<0.05$.

\section{RESULTS}

Anthracnose occurrence and fruit yield affected by root treatment of rhizobacteria in the plastic house. In the 2008 test, four strains (CCR80, GSE09, ISE13, and ISE14) significantly $(P<0.05)$ reduced anthracnose incidence on red and combined fruit at first harvest compared with the buffer-treated controls; two strains (CCR04 and GSE09) significantly $(P<0.05)$ reduced the disease on red and combined fruit at second harvest (Fig. 3A and B). However, all tested strains failed to reduce disease incidence on green fruit at first and second harvests, except strain CCR04 at second harvest (Fig. 3A and B). Similar results were observed in the 2009 test (Fig. 3C and D). All strains significantly $(P<0.05)$ reduced the disease on red and combined fruit at first harvest compared with the controls; strain ISE14 only significantly $(P<0.05)$ reduced the disease of green fruit (Fig. $3 \mathrm{C})$. However, all tested strains failed to reduce the disease on green, red, or combined fruit at second harvest (Fig. 3D). Overall, the bacterial treatments inhibited the disease incidence of red fruit at first harvest better than at the second harvest over test years (Fig. 3). In the 2008 test, the reduction of anthracnose incidence in response to bacterial treatments was 34.1 to $58.5 \%$ on combined fruit of the first harvest and 26.9 to $53.8 \%$ on combined fruit of the second harvest compared with the controls. On the other hand, the disease reduction by the treatment in the 2009 test was 49.3 to $61.6 \%$ on combined fruit of the first harvest and 30.3 to $40.9 \%$ on combined fruit of the second harvest compared with the controls.

Pepper fruit yields, including numbers of green and red fruit and fresh weight of red fruit, were affected by the treatments of bacterial strains compared with the buffer-treated controls (Table 1). In the 2008 test, four strains (CCR04, GSE09, ISE13, and ISE14) significantly $(P<0.05)$ increased the numbers of red and combined fruit compared with the controls; strain GSE09 only increased green fruit at first harvest. At second harvest, three strains (GSE09, ISE13, and ISE14) increased the number of green fruit compared with the control; strain GSE09 only increased that of combined fruit. However, these bacterial strains failed to increase red fruit at second harvest. Furthermore, strain GSE09 significantly $(P<0.05)$ increased the fresh weight of red pepper fruit in combined data of two harvests compared with the control (Table 1). In the 2009 test, all five strains failed to increase the number of green, red, and combined fruit at the first harvest compared with the controls; however, strains GSE09 and ISE14 significantly $(P<0.05)$ increased numbers of green, red, and combined fruit at second harvest compared with the controls. In terms of the fresh weight of red pepper fruit, strains GSE09 and ISE14 significantly $(P<0.05)$ affected the fruit weights, except the first harvest for strain ISE14 (Table 1). Overall, strains GSE09 and ISE14 consistently produced higher numbers of green and red

TABLE 3. Effects of volatiles produced by antagonistic bacterial strains CCR04, CCR80, GSE09, ISE13, and ISE14 or $10 \mathrm{mM} \mathrm{MgSO}_{4}$ buffer (control) on pepper ('Nockwang') fruit ripening from green (unripe) to red (ripe)

\begin{tabular}{lccc}
\hline & & \multicolumn{2}{c}{ Ripening index $(0 \text { to } 4)^{\mathrm{z}}$} \\
\cline { 3 - 4 } Treatment $^{\mathrm{x}}$ & Fruit ripening $(\%)^{\mathrm{y}}$ & Median & Rank \\
\hline Control & $2.5 \pm 1.6 \mathrm{c}$ & 0.0 & $38.6 \pm 3.9 \mathrm{~d}$ \\
CCR04 & $15.0 \pm 4.9 \mathrm{c}$ & 0.0 & $54.2 \pm 5.9 \mathrm{c}$ \\
CCR80 & $12.1 \pm 6.1 \mathrm{c}$ & 0.0 & $44.6 \pm 5.5 \mathrm{~cd}$ \\
GSE09 & $81.0 \pm 5.4 \mathrm{a}$ & 3.0 & $102.6 \pm 2.4 \mathrm{a}$ \\
ISE13 & $40.5 \pm 9.8 \mathrm{~b}$ & 2.0 & $70.1 \pm 7.8 \mathrm{~b}$ \\
ISE14 & $10.5 \pm 3.6 \mathrm{c}$ & 0.0 & $49.2 \pm 5.0 \mathrm{~cd}$ \\
\hline
\end{tabular}

${ }^{\mathrm{x}}$ Each bacterial strain suspension or $10 \mathrm{mM} \mathrm{MgSO}_{4}$ buffer (control) was smeared on nutrient agar in small plastic petri dishes. Surface-sterilized green (unripe) pepper fruit ( $>8 \mathrm{~cm}$ long) and bacteria-smeared small petri dishes were placed in large plastic square plates at the same time and then incubated at $28^{\circ} \mathrm{C}$ with fluorescent light at $16 \mathrm{~h} /$ day.

y Fruit ripening was also evaluated as the percent color change from green (unripe) to red (ripe) 8 and 10 days after incubation for experiments 1 and 2, respectively. Means \pm standard errors followed by the same letters are not significantly different according to the LSD test at $P<0.05$. Arcsine square root-transformed data were used for statistical analysis of pepper ripening; however, untransformed data are presented. Values are means of 20 replications.

${ }^{\mathrm{z}}$ Fruit ripening was assessed based on a ripening index $(0$-to- 4 scale, where $0=$ green, $1=$ breaking, $2=<50 \%, 3=50$ to $89 \%$, and $4=\geq 90 \%$ red color of a fruit). Mean ranks \pm standard errors followed by the same letter within a column are not significantly different according to the nonparametric rank test followed by the least significant difference (LSD) test at $P<0.05$. Values are means of 20 replications.

TABLE 2. Numbers and fresh weights of green (unripe) and red (ripe) fruit from pepper ('Nockwang') plants after transplanting seedlings treated with antagonistic bacterial strains CCR04, CCR80, GSE09, ISE13, and ISE14 or $10 \mathrm{mM} \mathrm{MgSO}_{4}$ buffer (control) in the field in 2008 and $2009^{\mathrm{y}}$

\begin{tabular}{|c|c|c|c|c|c|c|}
\hline \multirow[b]{2}{*}{ Year, treatment ${ }^{\mathrm{z}}$} & \multicolumn{3}{|c|}{ Number of pepper fruit } & \multicolumn{3}{|c|}{ Fresh weight of pepper fruit $(\mathrm{kg})$} \\
\hline & Green & Red & Combined & Green & Red & Combined \\
\hline \multicolumn{7}{|l|}{2008} \\
\hline Control & $99.3 \pm 0.8 \mathrm{a}$ & $21.3 \pm 5.3 b$ & $120.7 \pm 5.5 b$ & $0.98 \pm 0.01 \mathrm{~b}$ & $0.22 \pm 0.06 \mathrm{~b}$ & $1.20 \pm 0.17 \mathrm{~b}$ \\
\hline CCR04 & $97.3 \pm 9.3 \mathrm{a}$ & $36.0 \pm 4.4 \mathrm{ab}$ & $133.3 \pm 6.8 \mathrm{ab}$ & $1.41 \pm 0.14 \mathrm{ab}$ & $0.48 \pm 0.08 \mathrm{ab}$ & $1.90 \pm 0.16 \mathrm{ab}$ \\
\hline CCR80 & $119.7 \pm 17.3 \mathrm{a}$ & $33.0 \pm 2.8 \mathrm{ab}$ & $152.7 \pm 18.3 \mathrm{ab}$ & $1.74 \pm 0.25 \mathrm{a}$ & $0.45 \pm 0.06 \mathrm{ab}$ & $2.19 \pm 0.29 \mathrm{a}$ \\
\hline GSE09 & $114.5 \pm 19.1 \mathrm{a}$ & $32.3 \pm 3.1 \mathrm{ab}$ & $146.8 \pm 19.1 \mathrm{ab}$ & $1.63 \pm 0.30 \mathrm{ab}$ & $0.44 \pm 0.05 \mathrm{ab}$ & $2.07 \pm 0.30 \mathrm{a}$ \\
\hline ISE13 & $104.0 \pm 9.7 \mathrm{a}$ & $30.8 \pm 6.2 \mathrm{ab}$ & $134.8 \pm 6.4 \mathrm{ab}$ & $1.51 \pm 0.14 \mathrm{ab}$ & $0.45 \pm 0.09 \mathrm{ab}$ & $1.96 \pm 0.11 \mathrm{a}$ \\
\hline ISE14 & $134.0 \pm 18.9 \mathrm{a}$ & $40.0 \pm 9.1 \mathrm{a}$ & $174.0 \pm 26.1 \mathrm{a}$ & $1.95 \pm 0.28 \mathrm{a}$ & $0.58 \pm 0.13 \mathrm{a}$ & $2.53 \pm 0.38 \mathrm{a}$ \\
\hline \multicolumn{7}{|l|}{2009} \\
\hline Control & $43.8 \pm 7.8 \mathrm{a}$ & $17.3 \pm 4.6 \mathrm{c}$ & $61.0 \pm 5.5 \mathrm{c}$ & $0.60 \pm 0.08 \mathrm{a}$ & $0.30 \pm 0.10 b$ & $0.90 \pm 0.12 b$ \\
\hline CCR04 & $65.5 \pm 8.8 \mathrm{a}$ & $35.5 \pm 4.9 \mathrm{a}$ & $101.0 \pm 13.5 \mathrm{a}$ & $1.12 \pm 0.19 \mathrm{a}$ & $0.45 \pm 0.08 \mathrm{ab}$ & $1.58 \pm 0.27 \mathrm{a}$ \\
\hline CCR80 & $45.5 \pm 7.6 \mathrm{a}$ & $22.8 \pm 2.7 b c$ & $68.3 \pm 9.2 \mathrm{bc}$ & $0.67 \pm 0.17 \mathrm{a}$ & $0.33 \pm 0.06 \mathrm{ab}$ & $0.99 \pm 0.23 \mathrm{ab}$ \\
\hline GSE09 & $58.0 \pm 9.1 \mathrm{a}$ & $27.3 \pm 3.0 \mathrm{a}-\mathrm{c}$ & $85.3 \pm 11.0 \mathrm{a}-\mathrm{c}$ & $1.00 \pm 0.21 \mathrm{a}$ & $0.42 \pm 0.08 \mathrm{ab}$ & $1.42 \pm 0.26 \mathrm{ab}$ \\
\hline ISE13 & $69.3 \pm 4.2 \mathrm{a}$ & $31.3 \pm 4.1 \mathrm{ab}$ & $100.5 \pm 6.7 \mathrm{a}$ & $1.15 \pm 0.12 \mathrm{a}$ & $0.40 \pm 0.05 \mathrm{ab}$ & $1.54 \pm 0.14 \mathrm{ab}$ \\
\hline ISE14 & $60.8 \pm 15.7 \mathrm{a}$ & $34.3 \pm 2.9 \mathrm{a}$ & $95.0 \pm 13.3 \mathrm{ab}$ & $1.12 \pm 0.29 \mathrm{a}$ & $0.46 \pm 0.03 \mathrm{a}$ & $1.58 \pm 0.28 \mathrm{a}$ \\
\hline
\end{tabular}

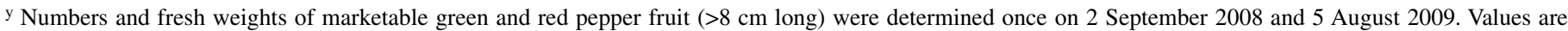
means \pm standard errors with four replications of 7 and 10 plants each in 2008 and 2009, respectively. Means \pm standard errors followed by same letters are not significantly different between treatments according to the least significant difference test at $P<0.05$.

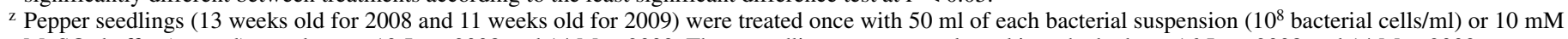
$\mathrm{MgSO}_{4}$ buffer (control) per plant on 13 June 2008 and 14 May 2009. These seedlings were transplanted into the beds on 16 June 2008 and 14 May 2009. 
fruit or increased the fresh weight of red fruit compared with the controls over the test years (Table 1). Compared with the controls, the number of combined fruit was increased by $32.5 \%$ with strain GSE09 and 30.4\% with strain ISE14 at the first harvest, and by $17.0 \%$ with strain GSE09 at the second harvest in the 2008 test; the number of combined fruit was increased by $65.3 \%$ with strain GSE09 and $61.0 \%$ with strain ISE14 at the second harvest in the 2009 test. The fresh weight of red pepper fruit combined from two harvests was increased by $18.8 \%$ with strain GSE09 compared with the control in the 2008 test, while the weight increase in the 2009 test was $86.1 \%$ with strain GSE09 and 53.2\% with strain ISE14.

Anthracnose occurrence and fruit yield affected by root treatment of rhizobacteria in the field. In the 2008 test, all bacterial strains significantly $(P<0.05)$ reduced anthracnose incidence on green, red, and combined pepper fruit compared with the buffer-treated controls (Fig. 4A). In the 2009 test, all five strains significantly $(P<0.05)$ reduced the disease incidence on green fruit compared with the control (Fig. 4B). However, strain CCR80 only significantly $(P<0.05)$ reduced the anthracnose on red fruit compared with the controls; strains CCR80, GSE09, and ISE13 significantly $(P<0.05)$ reduced the disease on combined fruit (Fig. 4B). The reduction of anthracnose incidence in response to bacterial treatments was 47.2 to $66.0 \%$ on combined fruit compared with the control in the 2008 test. In the 2009 test, the disease reduction was 27.3 to $54.7 \%$ on combined fruit compared with the control.
Pepper fruit yields were also affected by the bacterial treatments compared with the buffer-treated controls as observed in the plastic house tests (Table 2). In the 2008 test, strain ISE14 only significantly $(P<0.05)$ increased the number of red and combined fruit but not green fruit compared with the controls. However, in the case of weight of pepper fruit, strains CCR80, GSE09, ISE13, and ISE14 significantly $(P<0.05)$ increased the weight of either green, red, or combined fruit compared with the controls. In the 2009 test, strains CCR04, ISE13, or ISE14 significantly $(P<0.05)$ increased numbers of red and combined pepper fruit compared with the controls; strains CCR04 and ISE14 raised fresh weights of red or combined pepper fruit. Overall, strain ISE14 consistently produced higher numbers of red and combined pepper fruit or increased fresh weights of red and combined fruit compared with the controls over the test years (Table 2). The number of combined pepper fruit by the ISE14 treatment was increased by 44.2 and $55.7 \%$ compared with the controls in the 2008 and 2009 tests, respectively; the fresh weight of combined fruit was increased by 110.8 and $75.6 \%$ in the 2008 and 2009 tests, respectively.

Effects of bacterial volatiles on pepper fruit ripening. Volatiles produced by bacterial strains GSE09 and ISE13 significantly $(P<0.05)$ stimulated pepper fruit ripening compared with the buffer-treated control when they were evaluated by either the percent color change of green to red fruit or a ripening index (Fig. $1 \mathrm{~B}, 0$ [green] to 4 [ $\geq 90 \%$ red color of a fruit]; Table 3$)$. These two parameters (i.e., percent color change and ripening index) were

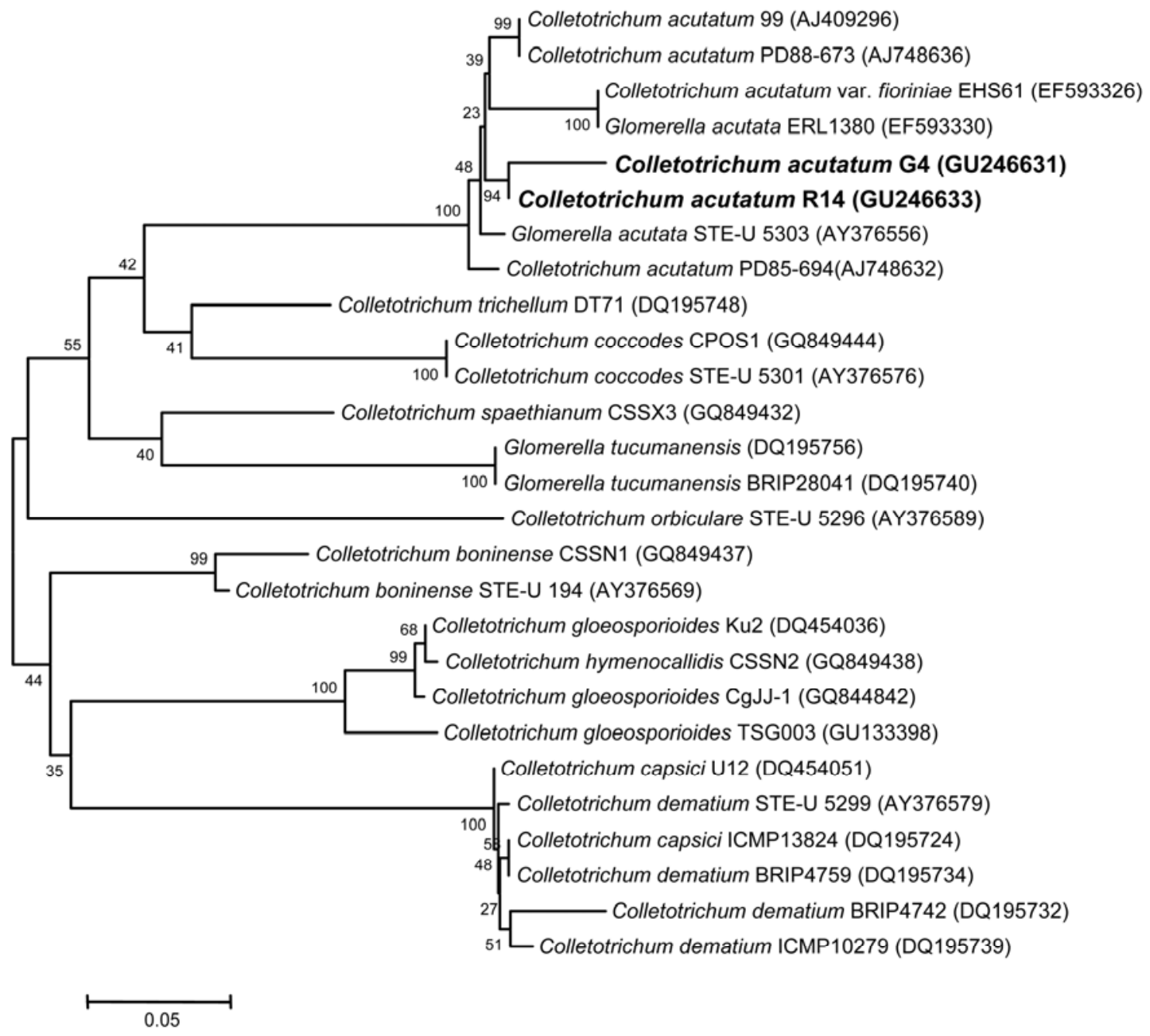

Fig. 5. Neighbor-joining tree of the Colletotrichum and Glomerella spp. related to Colletotrichum acutatum isolates G4 and R14 based on phylogenetic analysis of their $\beta$-tubulin gene partial sequences. Accession numbers at the GenBank of the National Center for Biotechnology Information of the U.S. National Library of Medicine, Bethesda, MD are indicated in parentheses. 
highly correlated $(r=0.958, P<0.0001)$; thus, the ripening index was useful for this purpose. However, the other strains (CCR04, CCR80, and ISE14) failed to stimulate significant $(P>0.05)$ ripening of the fruit while the control produced green or weak breaking color of the fruit (Table 3 ).

Effects of bacterial volatiles against $C$. acutatum and $P$. capsici. Volatiles produced by certain bacterial strains had biological activity in fruit ripening; thus, these bacteria were further examined for their activity on anthracnose and Phytophthora blight pathogens of pepper. First, to assess the effects of bacterial volatiles against anthracnose fungus, two isolates (G4 and R14) were obtained from typical lesions on either green or red fruit and identified as $C$. acutatum based on their molecular identification (Fig. 5). Consequently, the partial sequences of the $\beta$-tubulin gene of isolates G4 and R14 have been deposited in GenBank under accession numbers GU246631 and GU246633, respectively.

Volatiles produced by the tested bacterial strains inhibited mycelial growth, sporulation, conidial germination, or appressorium formation of $C$. acutatum isolates $\mathrm{G} 4$ and R14 on the I-plates
(Fig. 6A and B; Table 4). The inhibitory effects of the bacterial strains on both mycelial growth and sporulation of isolates G4 and R14 varied. Specifically, strains CCR80, GSE09, and ISE13 significantly $(P<0.05)$ inhibited both mycelial growth and sporulation of isolate $\mathrm{G} 4$, while strain CCR04 inhibited isolate R14 compared with the buffer-treated controls. However, all bacterial strains significantly $(P<0.05)$ inhibited both conidial germination and appressorium formation of both isolates, except strain ISE14, for germination of isolate G4 (Table 4). In addition, mycelia of isolates G4 and R14 were abnormally changed by volatiles from strains CCR04, CCR80, GSE09, and ISE13 but not by those of isolate ISE14. These abnormal changes included terminal or intercellular swellings, frequent branching, and selfcoiling of hyphae compared with the buffer-treated control (Fig. $6 \mathrm{~A}$ and $\mathrm{B})$.

Similar results were observed in isolate S197 of $P$. capsici (Fig. 6C; Table 4). All tested bacterial strains significantly $(P<0.05)$ inhibited mycelial growth (except strain ISE14) or zoospore production and germination of the isolate S197 compared with the
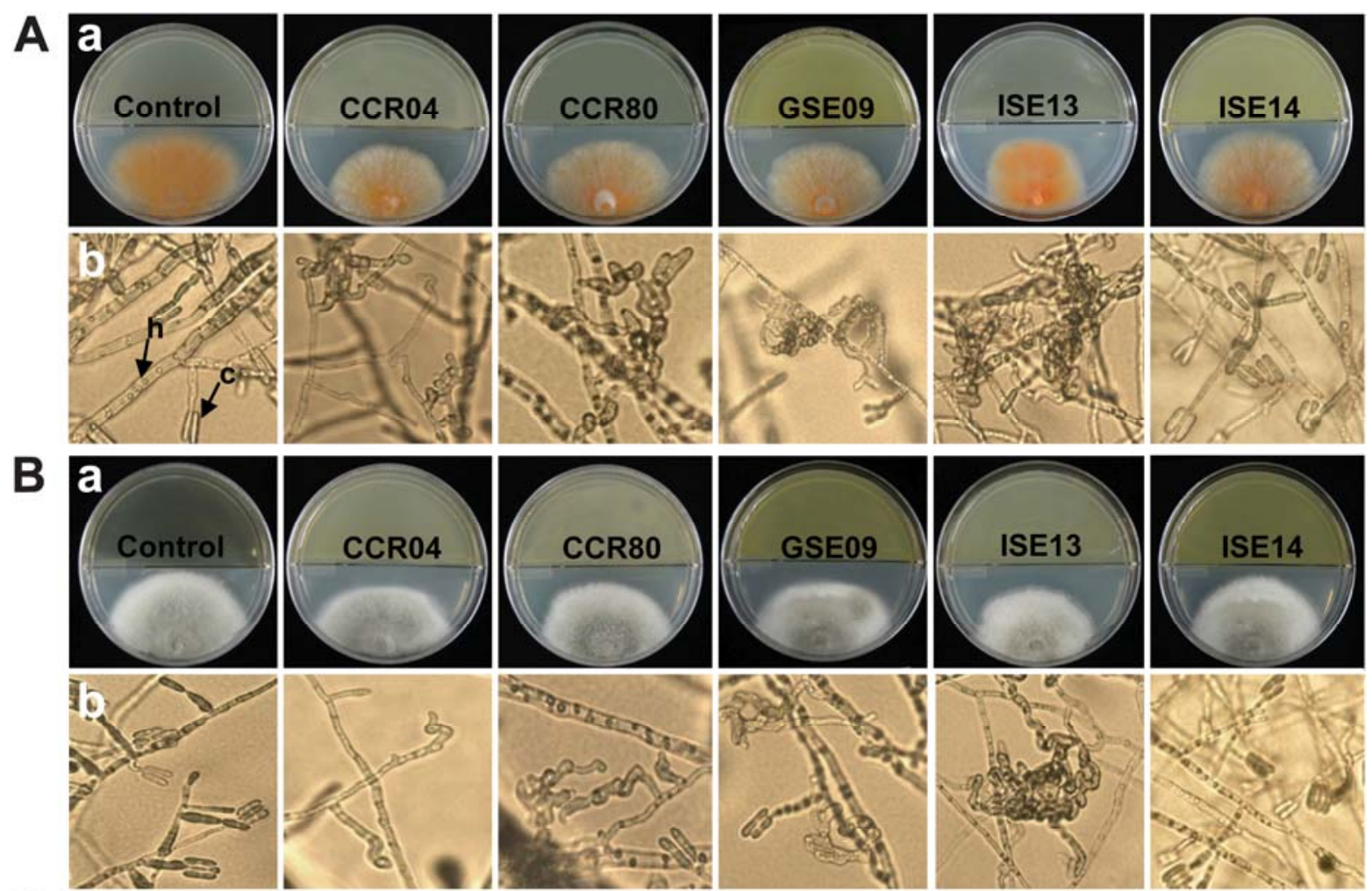

C
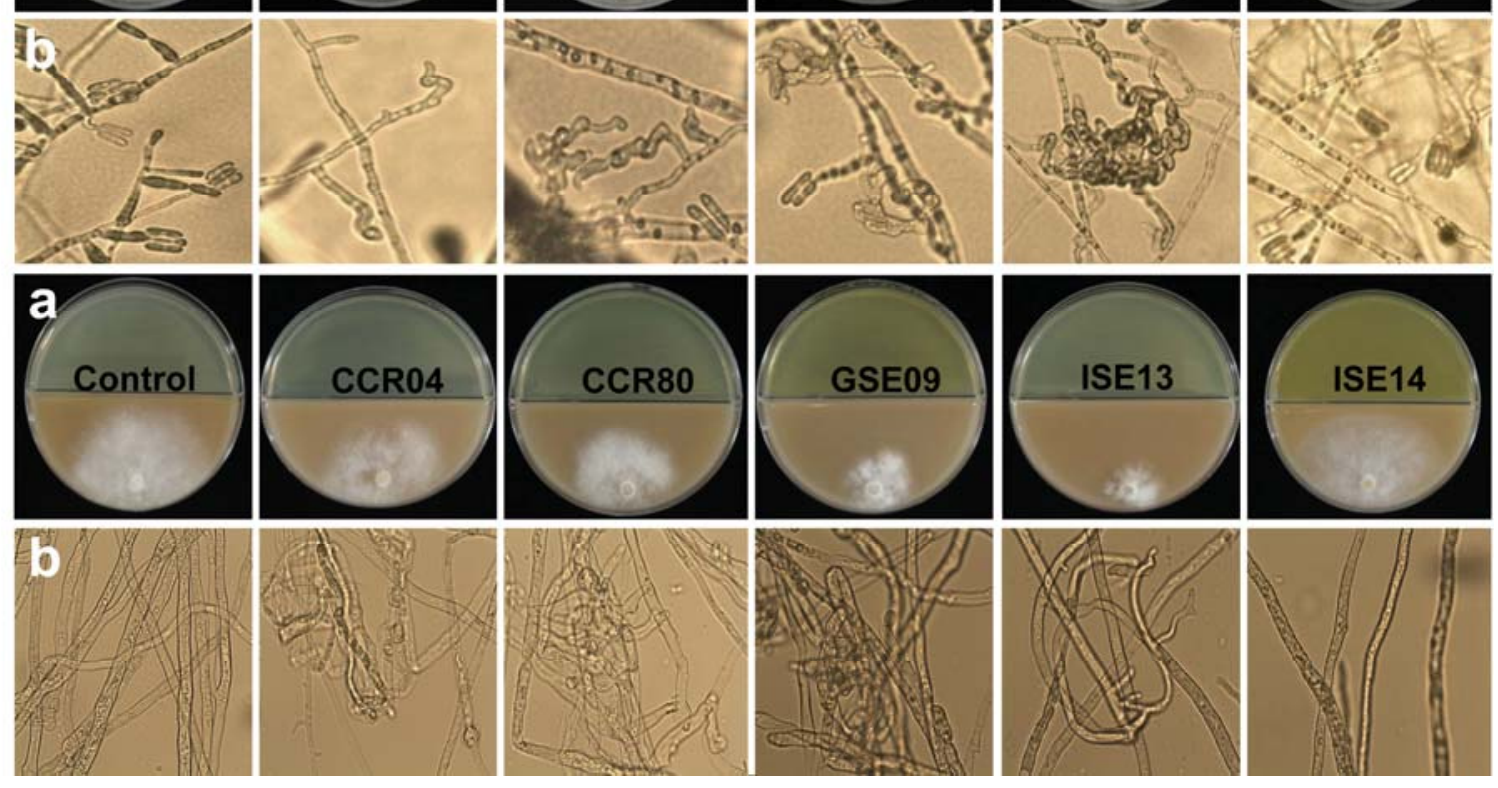

Fig. 6. Photographs of a, mycelial growth and b, morphology of Colletotrichum acutatum isolates A, G4 and B, R14, and Phytophthora capsici isolate C, S197 affected by volatiles produced by antagonistic bacterial strains CCR04, CCR80, GSE09, ISE13, and ISE14 or $10 \mathrm{mM} \mathrm{MgSO}_{4}$ buffer (control) 8 and 5 days after inoculation on I-plates, respectively. Each bacterial strain or $10 \mathrm{mM} \mathrm{MgSO}_{4}$ buffer was cultured on nutrient agar on one side of the I-plate, while $C$. acutatum or P. capsici was cultured on potato dextrose agar or V8 juice agar on the other side of the plate at the same time. In all, $100 \mu \mathrm{l}$ of each bacterial suspension or $10 \mathrm{mM}$ $\mathrm{MgSO}_{4}$ buffer was smeared on one side of the I-plates while 5-day-old mycelial plugs (5 mm in diameter) of C. acutatum or $P$. capsici were inoculated on the other side of the plates; $\mathrm{c}=$ conidia, $\mathrm{h}=$ hypha. 
buffer-treated controls (Table 4). In addition, volatiles from all strains except strain ISE14 produced morphological abnormalities in the mycelia of $P$. capsici compared with the control (Fig. 6C). The structural abnormalities of hyphae of $P$. capsici were intercalary swellings, stunting, and self-coiling of the hyphae (Fig. 6C).

Identification and biological activity of volatile compounds from strains GSE09 and ISE13. GC-MS analysis of volatiles produced by strains GSE09 and ISE13 revealed 17 distinct compounds (peak numbers [PN] 2 to 18) in both strains (Fig. 7A and $\mathrm{B}$ ) and another compound (PN 1) in strain GSE09 only (Fig. 7A). These tentatively identified compounds were conducted for GC-MS analysis by the addition of authentic compounds to volatiles of strains GSE09 and ISE13, respectively. The volatile compounds identified in both strains were decane (PN 2), dodecane (PN 8), 1,3-di-tert-butylbenzene (PN 9), tetradecane (PN 13), 2,4-di-tert-butylphenol (PN 17), and hexadecane (PN 18) (Fig. 7C and D; Supplemental Figure S1). However, these compounds were not detected in TSB medium control (Fig. 7E).

The identified volatile compounds decane, dodecane, 1,3-ditert-butylbenzene, tetradecane, and hexadecane failed to significantly $(P>0.05)$ stimulate fruit ripening in our initial experiments (Supplemental Table S1); however, 2,4-di-tert-butylphenol was further examined. As a result, 2,4-di-tert-butylphenol significantly $(P<0.05)$ stimulated pepper fruit ripening compared with the solvent or buffer control when they were evaluated by either the percent color change of green to red fruit or a ripening index (Table 5). In addition, the bacterial strains GSE09 and ISE13 themselves significantly $(P<0.05)$ stimulated fruit ripening while the solvent or buffer control produced green or weak breaking color of the fruit (Table 5).

Likewise, the identified compounds, except 2,4-di-tert-butylphenol, failed to significantly $(P>0.05)$ inhibit the growth and development of $C$. acutatum isolate R14 in our initial experiments (Supplemental Table S2); thus, 2,4-di-tert-butylphenol was further examined on C. acutatum isolates $\mathrm{G} 4$ and R14 and
P. capsici isolate S197. The volatile compound 2,4-di-tertbutylphenol significantly $(P<0.05)$ inhibited mycelial growth, sporulation, spore germination, or appressorium formation of $C$. acutatum and $P$. capsici isolates on the I-plates compared with the solvent or buffer controls (Table 6). Similarly, the bacterial strains GSE09 and ISE13 themselves also significantly $(P<0.05)$ inhibited mycelial growth, sporulation, spore germination, or appressorium formation of $C$. acutatum and $P$. capsici isolates (Table 6).

\section{DISCUSSION}

Rhizobacteria have been studied for the control of airborne plant diseases; thus, we investigated the effects of rhizobacteria antagonistic to Phytophthora blight of pepper by $P$. capsici, not only on biocontrol activity against anthracnose of pepper fruit by C. acutatum but also on plant growth-promoting activity, including ripening and yield of the fruit in the plastic house and field for 2 years. This study demonstrated that the tested bacterial strains significantly and effectively reduced anthracnose of pepper fruit and stimulated fruit ripening from green (unripe) to red (ripe) and an increase of fruit yield.

Many antagonistic rhizobacteria have been used in attempts to control various foliar diseases such as gray mold of cucumber caused by Botrytis cinerea, white mold of cucumber by S. sclerotiorum, anthracnose of cucumber by $C$. orbiculare, downy mildew of pearl millet by Sclerospora graminicola, powdery mildew of melon by Sphaerotheca fusca, and Alternaria leaf spot of sweet pepper by Alternaria alternata $(21,36,44,52,55)$. Antagonistic rhizobacteria that produce antibiotics (9) or fungal cell-walldegrading enzymes such as chitinase (53) were sometimes sprayed on foliar parts of the plants to reduce diseases through direct suppression of development and infection of the fungal pathogens (3). However, rhizobacteria are usually treated in soil, seed, or seedlings and they reduce the diseases through induction of local or systemic resistance in plants $(7,27,42)$. In this regard, certain

TABLE 4. Effect of volatiles produced by antagonistic bacterial strains CCR04, CCR80, GSE09, ISE13, and ISE14 or $10 \mathrm{mM} \mathrm{MgSO}_{4}$ buffer (control) on mycelial growth, sporulation, germination, or appressorium formation of Colletotrichum acutatum isolates G4 and R14 and Phytophthora capsici isolate S197 on I-plates ${ }^{\mathrm{x}}$

\begin{tabular}{|c|c|c|c|c|}
\hline Isolate, treatment ${ }^{\mathrm{y}}$ & Mycelial growth $(\mathrm{mm})^{\mathrm{z}}$ & Sporulation (log no. spores $/ \mathrm{cm}^{2}$ ) & Germination (\%) & Appressorium (\%) \\
\hline \multicolumn{5}{|c|}{ C. acutatum isolate $\mathrm{G} 4$} \\
\hline Control & $23.1 \pm 1.0 \mathrm{a}$ & $5.53 \pm 0.01 \mathrm{a}$ & $86.5 \pm 2.4 \mathrm{a}$ & $83.0 \pm 2.2 \mathrm{a}$ \\
\hline CCR04 & $17.3 \pm 1.0 \mathrm{~cd}$ & $5.69 \pm 0.02 \mathrm{a}$ & $55.0 \pm 6.8 \mathrm{bc}$ & $44.5 \pm 6.5 b$ \\
\hline GSE09 & $16.7 \pm 0.9 \mathrm{~d}$ & $4.96 \pm 0.04 \mathrm{bc}$ & $60.5 \pm 3.5 \mathrm{~b}$ & $41.0 \pm 3.3 \mathrm{~b}$ \\
\hline ISE13 & $19.6 \pm 1.0 \mathrm{bc}$ & $5.20 \pm 0.04 \mathrm{~b}$ & $56.0 \pm 4.7 \mathrm{bc}$ & $46.3 \pm 2.8 \mathrm{~b}$ \\
\hline ISE14 & $21.7 \pm 1.3 \mathrm{ab}$ & $4.86 \pm 0.03 \mathrm{c}$ & $76.1 \pm 2.9 \mathrm{a}$ & $75.0 \pm 1.7 \mathrm{a}$ \\
\hline \multicolumn{5}{|c|}{ C. acutatum isolate R14 } \\
\hline CCR80 & $24.4 \pm 1.9 \mathrm{a}$ & $4.84 \pm 0.04 b$ & $78.1 \pm 3.5 \mathrm{bc}$ & $56.7 \pm 9.6 \mathrm{~b}$ \\
\hline GSE09 & $22.8 \pm 2.4 \mathrm{a}-\mathrm{c}$ & $5.02 \pm 0.04 \mathrm{a}$ & $76.6 \pm 2.2 \mathrm{bc}$ & $54.3 \pm 8.4 \mathrm{~b}$ \\
\hline ISE13 & $21.5 \pm 1.3 \mathrm{c}$ & $5.08 \pm 0.02 \mathrm{a}$ & $68.9 \pm 5.3 \mathrm{c}$ & $61.6 \pm 5.8 \mathrm{~b}$ \\
\hline ISE14 & $23.9 \pm 2.1 \mathrm{ab}$ & $5.18 \pm 0.03 \mathrm{a}$ & $75.0 \pm 1.7 \mathrm{c}$ & $67.1 \pm 1.7 \mathrm{~b}$ \\
\hline \multicolumn{5}{|c|}{ P. capsici isolate $\mathrm{S} 197$} \\
\hline Control & $30.4 \pm 0.8 \mathrm{a}$ & $3.97 \pm 0.10 \mathrm{a}$ & $83.2 \pm 3.9 \mathrm{a}$ & - \\
\hline CCR04 & $23.8 \pm 1.7 \mathrm{~b}$ & $3.60 \pm 0.07 \mathrm{~cd}$ & $7.5 \pm 0.7 \mathrm{c}$ & - \\
\hline
\end{tabular}

${ }^{x}$ Means \pm standard errors followed by same letters are not significantly different according to the least significant difference test at $P<0.05$. In germination or appressorium formation (\%), arcsine square root-transformed data were used for statistical analysis; however, untransformed data are presented. Values are means of eight replications except for zoospore sporulation (seven replications) of $P$. capsici isolate $\mathrm{S} 197 ;-=$ not available.

${ }^{y}$ In all, $100 \mu \mathrm{l}$ of each bacterial strain or $10 \mathrm{mM} \mathrm{MgSO}_{4}$ buffer (control) was smeared on nutrient agar on one side of the I-plate while 5-day-old mycelial plugs ( $5 \mathrm{~mm}$ in diameter) of each isolate of $C$. acutatum or P. capsici were inoculated on potato dextrose agar or V8 juice agar on the other side of the plate at the same time.

${ }^{\mathrm{z}}$ Mycelial growth of the isolates was measured when mycelia almost reached the center partition of the I-plate on which the other side was treated with $10 \mathrm{mM}$ $\mathrm{MgSO}_{4}$ buffer (control). Sporulation was determined as number of spores per square centimeter of mycelial growth in the plates. Suspensions of $C$. acutatum conidia or $P$. capsici zoospores were dropped on glass slides in moisturized petri dishes, and incubated at $28^{\circ} \mathrm{C}$ for $24 \mathrm{~h}$ or 2 to $4 \mathrm{~h}$. Percent germination and appressorium formation of the isolates were determined with $\approx 100$ spores/replication. 
volatile compounds produced by the rhizobacteria may play an important role in ISR and plant growth promotion $(46,47)$. Ryu et al. (47) found that volatiles produced by Bacillus subtilis and B. amyloliquefaciens reduced Pectobacterium carotovorum (Erwinia carotovora) through ISR in A. thaliana. In our current study, all tested rhizobacteria produced certain volatiles and reduced anthracnose incidence on green or red pepper fruit in the plastic house and field tests. This disease reduction on pepper fruit in response to root treatment with the rhizobacteria might suggest that the strains induced systemic resistance in the pepper plants. This ISR might be triggered by certain rhizobacteria-produced volatiles as elicitors in the pepper plants observed in this study.

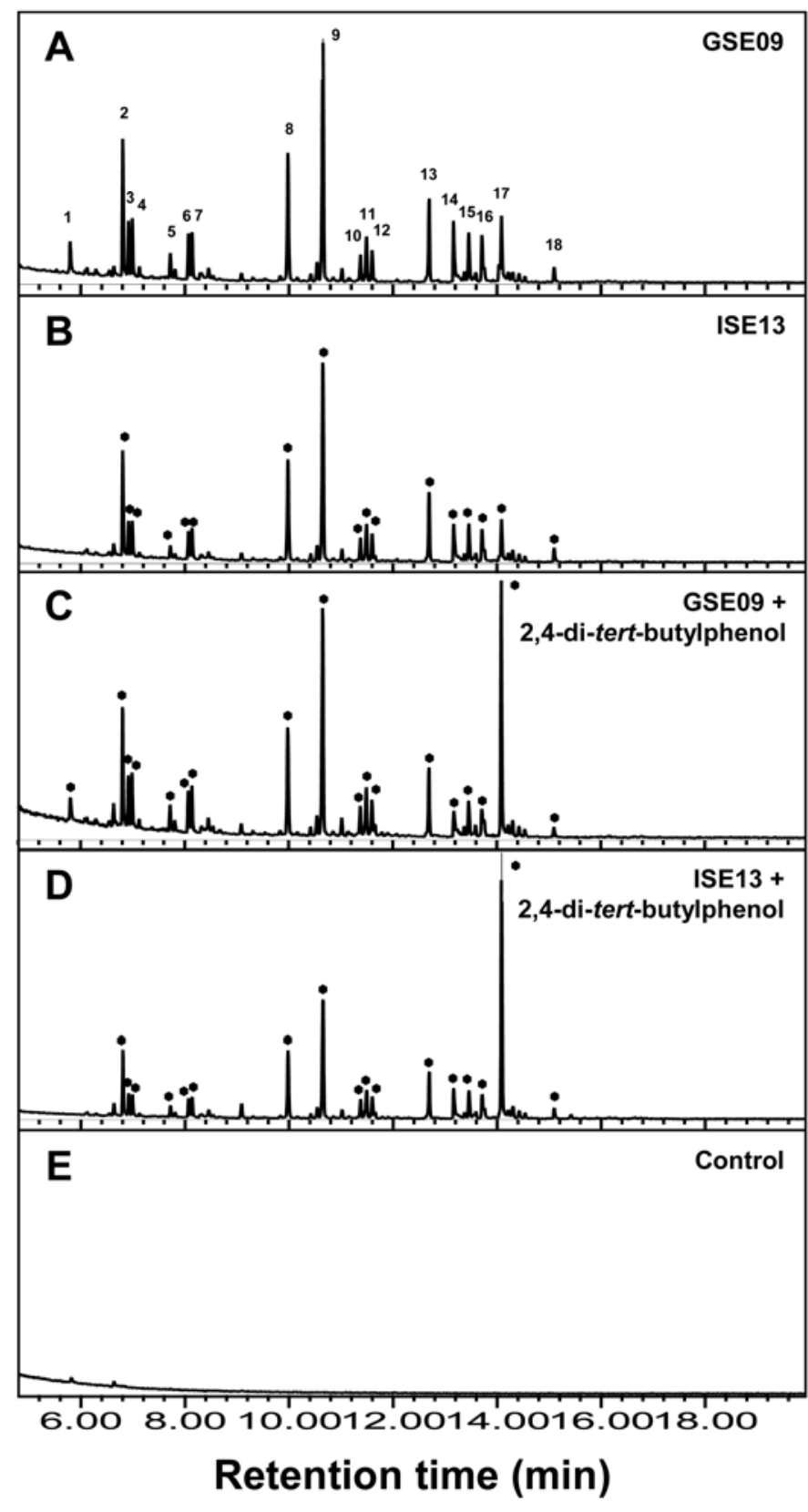

Fig. 7. Chromatographic profiles of volatiles produced by antagonistic bacterial strains A, GSE09 and B, ISE13 that were grown in tryptic soy broth (TSB) for $24 \mathrm{~h}$ at $28^{\circ} \mathrm{C}$. Identified compounds are decane (peak number [PN] 2), dodecane (PN 8), 1,3-di-tert-butylbenzene (PN 9), tetradecane (PN 13), 2,4-di-tert-butylphenol (PN 17), and hexadecane (PN 18). Chromatograms show the identification of 2,4-di-tert-butylphenol by addition of the authentic compound to the volatiles of strains C, GSE09 and D, ISE13. E, No distinct volatile compounds were detected in the uninoculated TSB medium (control). Asterisks in chromatograms B, C, and D designate compounds that align with numbered peaks in chromatogram A.
Along with this, the anthracnose reduction on pepper fruit, or at least a part of it, might include the direct involvement of volatiles produced by the strains of plant roots tested in this study. This possibility was supported by the fact that bacterial volatiles inhibited development of anthracnose fungus $C$. acutatum such as mycelial growth, sporulation, conidial germination, or appressorium formation as observed in this study. In particular, the bacterial volatiles significantly inhibited the fungal infection process such as conidial germination and appressorium formation rather than mycelial growth and sporulation. Similar results were observed in the study by Arrebola et al. (2), in which volatile compounds produced by Bacillus strains had antifungal effects against Penicillium isolates, the causal agent of post-harvest decay in citrus. Moreover, plants have also been known to release volatile organic compounds in response to herbivore or pathogen attack, and the volatiles could also induce and prime plant defense in neighboring and undamaged plants (19).

Many PGPR induce plant growth promotion indirectly by preventing the deleterious effects of plant pathogens or rootassociated microorganisms, or directly by affecting physiological or nutritional mechanisms $(28,37)$. Certain PGPR are capable of producing plant hormones or growth regulators such as indole-3acetic acid and cytokinin, which play a role in plant growth stimulation (28). Moreover, PGPR could change soil $\mathrm{N}$ and $\mathrm{P}$ contents resulting from $\mathrm{N}_{2}$ fixation and phosphate solubilization, respectively, which could lead to plant growth promotion $(17,37)$. In this study, bacterial strains GSE09 and ISE14 consistently stimulated pepper fruit ripening (increased numbers or weight of red fruit) and the yield of green and red fruit in the plastic house and field over a 2-year test. In the case of strain GSE09, stimulation of fruit ripening and yield might be due to the effects of the bacterial cells themselves or certain volatiles produced by the strain on plant physiology, including signal transduction related to fruit ripening and plant growth. Likewise, the volatile compounds of strain GSE09 might directly induce fruit ripening, as we observed in the laboratory tests. This assumption might be explained by the observations in our plastic house and field tests. Strain GSE09 induced fruit ripening in the house tests (relatively closed

TABLE 5. Effects of the volatile compound 2,4-di-tert-butylphenol, produced by antagonistic bacterial strains GSE09 and ISE13, on pepper ('Nockwang') fruit ripening from green (unripe) to red (ripe)

\begin{tabular}{lccc}
\hline & & \multicolumn{2}{c}{ Ripening index $(0 \text { to } 4)^{\mathrm{z}}$} \\
\cline { 3 - 4 } Treatment $^{\mathrm{x}}$ & Fruit ripening $(\%)^{\mathrm{y}}$ & Median & Rank \\
\hline Solvent & $4.5 \pm 2.3 \mathrm{~b}$ & 0.0 & $26.3 \pm 3.0 \mathrm{~b}$ \\
MgSO $_{4}$ buffer & $7.5 \pm 3.2 \mathrm{~b}$ & 0.0 & $29.8 \pm 3.9 \mathrm{~b}$ \\
2,4-Di-tert-butylphenol & $47.9 \pm 7.8 \mathrm{a}$ & 2.0 & $63.6 \pm 3.8 \mathrm{a}$ \\
GSE09 & $61.5 \pm 8.4 \mathrm{a}$ & 3.0 & $69.2 \pm 5.5 \mathrm{a}$ \\
ISE13 & $52.0 \pm 9.6 \mathrm{a}$ & 2.5 & $61.8 \pm 6.5 \mathrm{a}$ \\
\hline
\end{tabular}

${ }^{x}$ Treatments consisting of $5 \mathrm{ml}$ of 2,4-di-tert-butylphenol $(100 \mu \mathrm{g} / \mathrm{ml})$ dissolved in sterile distilled water containing $2 \%$ ( $\mathrm{vol} / \mathrm{vol})$ dimethyl sulfoxide and $0.001 \%$ (vol/ $/ \mathrm{vol}$ ) Tween 20 or the solvent alone (solvent control) were directly applied to the small plastic petri dishes; $100 \mu \mathrm{l}$ of each bacterial strain suspension or $10 \mathrm{mM} \mathrm{MgSO}_{4}$ buffer (buffer control) were smeared on tryptic soy agar on the dishes. Surface-sterilized green pepper fruit $(>8 \mathrm{~cm}$ long) and chemical, bacteria, or buffer-treated small plastic petri dishes were placed in large plastic square plates at the same time and then incubated at $28^{\circ} \mathrm{C}$ with fluorescent light a $16 \mathrm{~h} /$ day.

${ }^{y}$ Fruit ripening was also evaluated as the percent color change from green to red 8 days after incubation. Means \pm standard errors followed by the same letters are not significantly different according to the LSD test at $P<0.05$. Arcsine square root-transformed data were used for statistical analysis of pepper ripening; however, untransformed data are presented. Values are means of 20 replications.

${ }^{\mathrm{z}}$ Fruit ripening was assessed based on a ripening index (0-to-4 scale, where $0=$ green, $1=$ breaking, $2=<50 \%, 3=50$ to $89 \%$, and $4=\geq 90 \%$ red color of a fruit). Mean ranks \pm standard errors followed by the same letter within a column are not significantly different according to the nonparametric rank test followed by the least significant difference (LSD) test at $P<0.05$. Values are means of 20 replications. 
condition) but failed to do so in the field tests (open condition). This implies that bacterial volatiles might affect the ripening somewhat due to the lack of air circulation in the house.

On the other hand, strain ISE14, which did not produce volatiles for fruit ripening in our laboratory tests, promoted fruit ripening and yield regardless of the plastic house and field conditions. Strain ISE14 has the ability to increase phosphate solubility in the rhizosphere (48), and this might affect the fruit ripening and yield. Richkard (43) and Han et al. (18) reported that treatment with phosphate-solubilizing bacteria or available phosphate as fertilizers improved pepper growth and production. In addition, stimulation of pepper fruit ripening by these strains would not be dependent on ethylene production by the strains. Because maturation of pepper fruit as a nonclimateric fruit is not regulated by ethylene (41), stimulation of fruit ripening by strains GSE09 and ISE14 might be related to physiological alterations by certain volatiles except ethylene, or their direct effects on the fruit. Moreover, the volatiles from the bacterial strains tested in this study also inhibited the mycelial growth, sporulation, or zoospore germination of $P$. capsici. This implies that the volatiles could affect soilborne plant pathogens or deleterious microorganisms, inducing fungistasis $(8,31,45)$. Consequently, this inhibition might generate healthy plant roots and increase plant growth and yield.

Attempts were made to identify the volatile compounds produced by the rhizobacteria, especially strains GSE09 and ISE13, which not only stimulated fruit ripening but also inhibited pathogen growth and development in this study. The GC-MS analysis of the bacterial volatiles revealed 17 distinct compounds, including decane, dodecane, 1,3-di-tert-butylbenzene, tetradecane, 2,4-di-tert-butylphenol, and hexadecane, in both strains. Among these compounds, 2,4-di-tert-butylphenol exhibited significant and consistent activities on fruit ripening as well as growth and development of $C$. acutatum and $P$. capsici, as observed in bacterial strains GSE09 and ISE13 themselves. This compound (2,4-di-tert-butylphenol) has been also found in plant extracts or plant essential oils with antibacterial or antioxidant activities $(39,57)$ because phenols had been described as antioxidants, growth regulators, or flavors (26). Recently, Tayung et al. (54) reported that metabolites, including 2,4-di-tert-butylphenol and hydrocarbons, from an endophytic Fusarium sp. had antifungal activities against postharvest pathogens such as $F$. oxysporum, Aspergillus niger, and Rhizopus stolonifer. These findings indicate that 2,4-di-tert-butylphenol might be produced not only by plants or fungi but also by bacteria. Furthermore, 2,4-di-tertbutylphenol produced by rhizobacteria was related to fruitripening stimulation and plant-pathogen inhibition in this study.

In our previous study (49), we demonstrated that the five tested bacterial strains used in this study were effective to control Phytophthora blight of pepper. Among the five tested strains, two strains (GSE09 and ISE14) effectively reduced anthracnose, possibly through ISR or direct effect of bacterial volatiles; these strains stimulated pepper fruit ripening from green (unripe) to red (ripe) and yields, possibly through plant physiological alterations by the volatiles or their direct effects on pepper fruit. In addition, in the case of strain ISE14, factors affecting fruit ripening and yield may involve other mechanisms such as enhancement of phosphate solubility. Therefore, strains GSE09 and ISE14 could be potential agents for controlling not only Phytophthora blight by the soilborne pathogen $P$. capsici but also anthracnose by the airborne pathogen, $C$. acutatum, as well as for increasing pepper fruit ripening and yield. To our knowledge, this is the first report of volatiles such as 2,4-di-tert-butylphenol produced by rhizobacteria related to not only pepper fruit ripening from green (unripe) to red (ripe) but also inhibition of plant pathogens such as $C$. acutatum and $P$. capsici.

\section{ACKNOWLEDGMENTS}

This study was conducted with the support of a grant from Korea University, Seoul, Korea. We thank the Deokso Experiment Farm of Korea University, which allowed us to conduct the commercial, plastic

TABLE 6. Effect of the volatile compound 2,4-di-tert-butylphenol, produced by antagonistic bacterial strains GSE09 and ISE13, on mycelial growth, sporulation, germination, or appressorium formation of Colletotrichum acutatum isolates G4 and R14 and Phytophthora capsici isolate S197 on I-plates ${ }^{\mathrm{X}}$

\begin{tabular}{|c|c|c|c|c|}
\hline Isolate, treatment ${ }^{\mathrm{y}}$ & Mycelial growth $(\mathrm{mm})^{\mathrm{z}}$ & Sporulation (log no. spores $/ \mathrm{cm}^{2}$ ) & Germination $(\%)$ & Appressorium (\%) \\
\hline \multicolumn{5}{|l|}{ C. acutatum isolate $\mathrm{G} 4$} \\
\hline Solvent & $25.8 \pm 0.3 \mathrm{a}$ & $5.81 \pm 0.03 \mathrm{a}$ & $88.6 \pm 0.7 \mathrm{a}$ & $86.5 \pm 1.2 \mathrm{a}$ \\
\hline $\mathrm{MgSO}_{4}$ buffer & $24.9 \pm 0.3 \mathrm{a}$ & $5.83 \pm 0.02 \mathrm{a}$ & $90.0 \pm 0.6 \mathrm{a}$ & $90.0 \pm 0.8 \mathrm{a}$ \\
\hline GSE09 & $16.6 \pm 0.9 \mathrm{bc}$ & $5.24 \pm 0.05 b$ & $59.9 \pm 1.7 \mathrm{c}$ & $8.3 \pm 1.5 \mathrm{c}$ \\
\hline ISE13 & $15.8 \pm 0.9 \mathrm{c}$ & $5.12 \pm 0.04 \mathrm{c}$ & $63.3 \pm 1.9 b c$ & $13.0 \pm 1.6 \mathrm{~b}$ \\
\hline \multicolumn{5}{|l|}{ C. acutatum isolate R14 } \\
\hline Solvent & $24.8 \pm 0.4 \mathrm{a}$ & $4.72 \pm 0.01 \mathrm{a}$ & $88.8 \pm 0.6 \mathrm{a}$ & $87.7 \pm 0.9 \mathrm{a}$ \\
\hline GSE09 & $16.9 \pm 0.5 \mathrm{c}$ & $4.36 \pm 0.05 b c$ & $16.1 \pm 1.0 \mathrm{c}$ & $11.9 \pm 1.0 \mathrm{~d}$ \\
\hline ISE13 & $19.6 \pm 0.9 \mathrm{~b}$ & $4.39 \pm 0.04 b$ & $28.0 \pm 1.4 \mathrm{~b}$ & $21.7 \pm 1.7 \mathrm{c}$ \\
\hline \multicolumn{5}{|l|}{ P. capsici isolate $\mathrm{S} 197$} \\
\hline Solvent & $24.3 \pm 0.4 \mathrm{a}$ & $3.99 \pm 0.04 \mathrm{a}$ & $86.9 \pm 1.0 \mathrm{a}$ & - \\
\hline $\mathrm{MgSO}_{4}$ buffer & $23.8 \pm 0.3 \mathrm{a}$ & $4.08 \pm 0.02 \mathrm{a}$ & $89.0 \pm 0.9 \mathrm{a}$ & - \\
\hline 2,4-Di-tert-butylphenol & $17.0 \pm 0.4 \mathrm{c}$ & $3.56 \pm 0.09 \mathrm{~b}$ & $22.7 \pm 1.0 \mathrm{~b}$ & - \\
\hline GSE09 & $18.4 \pm 0.4 \mathrm{~b}$ & $3.34 \pm 0.05 \mathrm{c}$ & $11.2 \pm 1.3 \mathrm{c}$ & - \\
\hline
\end{tabular}

${ }^{\mathrm{x}}$ Means \pm standard errors followed by same letters are not significantly different according to the least significant difference test at $P<0.05$. In germination or appressorium formation (\%), arcsine square root-transformed data were used for statistical analysis; however, untransformed data are presented. Values are means of eight replications; $-=$ not available.

${ }^{y}$ Treatments consisting of $5 \mathrm{ml}$ of 2,4-di-tert-butylphenol $(100 \mu \mathrm{g} / \mathrm{ml}$ ) dissolved in sterile distilled water containing $2 \%$ (vol/vol) dimethyl sulfoxide and $0.001 \%$ ( $\mathrm{vol} / \mathrm{vol}$ ) Tween 20 or the solvent alone (solvent control) were directly applied to the one side of the I-plate; $100 \mu \mathrm{l}$ of each bacterial strain suspension or $10 \mathrm{mM}$ $\mathrm{MgSO}_{4}$ buffer (buffer control) was smeared on tryptic soy agar on the same side of the I-plate. At the same time, 5-day-old mycelial plugs (5 mm in diameter) of each isolate of $C$. acutatum or $P$. capsici were inoculated on potato dextrose agar or V8 juice agar amended with streptomycin ( $50 \mu \mathrm{g} / \mathrm{ml})$ on the other side of the plate.

${ }^{z}$ Mycelial growth of the isolates was measured when mycelia almost reached the center partition of the I-plate on which the other side was treated with sterile distilled water containing $2 \%$ (vol/vol) dimethyl sulfoxide and $0.001 \%$ (vol $/ \mathrm{vol})$ Tween 20 (solvent control). Sporulation was determined as number of spores per square centimeter of mycelial growth in the plates. Suspensions of $C$. acutatum conidia or $P$. capsici zoospores were dropped on glass slides in moisturized petri dishes and incubated at $28^{\circ} \mathrm{C}$ for $24 \mathrm{~h}$ or 2 to $4 \mathrm{~h}$. Percent germination and appressorium formation of the isolates were determined with $\approx 100$ spores/replication. 
house tests; H. J. Kim and M. J. Kim for their technical help in the house and field tests; and B. K. Hwang, C.-M. Ryu, and H. W. Jung for their valuable comments on this manuscript.

\section{LITERATURE CITED}

1. Anand, T., Chandrasekaran, A., Kuttalam, S., Senthilraja, G., and Samiyappan, R. 2010. Integrated control of fruit rot and powdery mildew of chili using the biocontrol agent Pseudomonas fluorescens and a chemical fungicide. Biol. Control 52:1-7.

2. Arrebola, E., Sivakumar, D., and Korsten, L. 2010. Effect of volatile compounds produced by Bacillus strains on postharvest decay in citrus. Biol. Control 53:122-128.

3. Bardas, G. A., Lagopodi, A. L., Kadoglidou, K., and Tzavella-Klonari, K. 2009. Biological control of three Colletotrichum lindemuthianum races using Pseudomonas chlororaphis PCL1391 and Pseudomonas fluorescens WCS365. Biol. Control 49:139-145.

4. Chanchaichaovivat, A., Panijpan, B., and Ruenwongsa, P. 2008. Putative modes of action of Pichia guilliermondii strain R13 in controlling chili anthracnose after harvest. Biol. Control 47:207-215.

5. Chanchaichaovivat, A., Ruenwongsa, P., and Panijpan, B. 2007. Screening and identification of yeast strains from fruits and vegetables: potential for biological control of postharvest chili anthracnose (Colletotrichum capsici). Biol. Control 42:326-335.

6. Chaurasia, B., Pandey, A., Palni, L. M. S., Trivedi, P., Kumar, B., and Colvin, N. 2005. Diffusible and volatile compounds produced by an antagonistic Bacillus subtilis strain cause structural deformations in pathogenic fungi in vitro. Microbiol. Res.160:75-81.

7. Chen, C., Belanger, R. R., Benhamou, N., and Paulitz, T. C. 2000. Defense enzymes induced in cucumber roots by treatment with plant growth-promoting rhizobacteria (PGPR) and Pythium aphanidermatum. Physiol. Mol. Plant Pathol. 56:13-23.

8. Chuankun, X., Minghe, M., Leming, Z., and Keqin, Z. 2004. Soil volatile fungistasis and volatile fungistatic compounds. Soil Biol. Biochem. 36:1997-2004

9. Ezziyyani, M., Requena, M. E., Egea-Gilabert, C., and Candela, M. E. 2007. Biological control of Phytophthora root rot of pepper using Trichoderma harzianum and Streptomyces rochei in combination. J. Phytopathol. 155:342-349.

10. Farag, M. A., Ryu, C.-M., Sumner, L. W., and Paré, P. W. 2006. GC-MS SPME profiling of rhizobacterial volatiles reveals prospective inducers of growth promotion and induced systemic resistance in plants. Phytochemistry 67:2262-2268.

11. Fernando, W. G. D., Ramarathnam, R., Krishnamoorthy, A. S., and Savchuk, S. C. 2005. Identification and use of potential bacterial organic antifungal volatiles in biocontrol. Soil Biol. Biochem. 37:955-964.

12. Freeman, S., Katan, T., and Shabi, E. 1998. Characterization of Colletotrichum species responsible for anthracnose diseases of various fruits. Plant Dis. 82:596-605.

13. Freeman, S., Pham, M., and Rodriguez, R. J. 1993. Molecular genotyping of Colletotrichum species based on arbitrarily primed PCR, A+T-rich DNA and nuclear DNA analyses. Exp. Mycol. 17:309-322.

14. Glass, N. L., and Donaldson, G. C. 1995. Development of primer sets designed for use with the PCR to amplify conserved genes from filamentous ascomycetes. Appl. Environ. Microbiol. 61:1323-1330.

15. Guo, J. H., Qi, H.-Y., Guo, Y.-H., Ge, H.-L., Gong, L.-Y., Zhang, L.-X., and Sun, P.-H. 2004. Biocontrol of tomato wilt by plant growthpromoting rhizobacteria. Biol. Control 29:66-72.

16. Gutiérrez-Luna, F. M, López-Bucio, J., Altamirano-Hernández, J., Valencia-Cantero, E., de la Cruz, H. R., and Macías-Rodríguez, L. 2010. Plant growth-promoting rhizobacteria modulate root-system architecture in Arabidopsis thaliana through volatile organic compound emission. Symbiosis 51:75-83.

17. Hamdali, H., Hafidi, M., Virolle, M. J., and Ouhdouch, Y. 2008. Growth promotion and protection against damping-off of wheat by two rock phosphate solubilizing actinomycetes in a P-deficient soil under greenhouse conditions. Appl. Soil Ecol. 40:510-517.

18. Han, H. S., Supanjani, and Lee, K. D. 2006. Effect of co-inoculation with phosphate and potassium solubilizing bacteria on mineral uptake and growth of pepper and cucumber. Plant Soil Environ. 52:130-136.

19. Heil, M., and Silva Bueno, J. C. 2007. Within-plant signaling by volatiles leads to induction and priming of an indirect plant defense in nature. Proc. Natl. Acad. Sci. USA 104:5467-5472.

20. Jetiyanon, K., and Kloepper, J. W. 2002. Mixtures of plant growthpromoting rhizobacteria for induction of systemic resistance against multiple plant diseases. Biol. Control 24:285-291.

21. Kamensky, M., Ovadis, M., Chet, I., and Chernin, L. 2003. Soil-borne strain IC14 of Serratia plymuthica with multiple mechanisms of antifungal activity provides biocontrol of Botrytis cinerea and Sclerotinia sclerotiorum diseases. Soil Biol. Biochem. 35:323-331.

22. Kim, H. S., Sang, M. K., Jeun, Y.-C. Hwang, B. K., and Kim, K. D. 2008. Sequential selection and efficacy of antagonistic rhizobacteria for controlling Phytophthora blight of pepper. Crop Prot. 27:436-443.

23. Kim, J. T., Park, S.-Y., Choi, W., Lee, Y.-H., and Kim, H. T. 2008. Characterization of Colletotrichum isolates causing anthracnose of pepper in Korea. Plant Pathol. J. 24:17-23.

24. Kim, K. D., Oh, B. J., and Yang, J. 1999. Differential interactions of a Colletotrichum gloeosporioides isolate with green and red pepper fruits. Phytoparasitica 27:97-106.

25. Kim, W. G., Cho, E. K., and Lee, E. J. 1986. Two strains of Colletotrichum gloeosporioides Penz. causing anthracnose on pepper fruits. Korean J. Plant Pathol. 2:107-113.

26. King, B. M., and Solms, J. 1982. Interactions of volatiles flavor compounds with propyl gallate and other phenols as compared with caffeine. J. Agric. Food Chem. 30:838-840.

27. Ku , J. 2001. Concepts and directions of induced systemic resistance in plants and its application. Eur. J. Plant Pathol. 107:7-12.

28. Lambrecht, M., Okon, Y., Vande Broek, A., and Vanderleyden, J. 2000. Indole-3-acetic acid: a reciprocal signaling molecule in bacteria-plant interactions. Trends Microbiol. 8:298-300.

29. Levene, H. 1960. Contributions to Probability and Statistics: Essays in Honor of Harold Hotelling. Stanford University Press, Stanford, CA.

30. Lewis Ivey, M. L., Nava-Diaz, C., and Miller, S. A. 2004. Identification and management of Colletotrichum acutatum on immature bell peppers. Plant Dis. 88:1198-1204.

31. Mackie, A. E., and Wheatley, R. E. 1999. Effects and incidence of volatile organic compound interactions between soil bacterial and fungal isolates. Soil Biol. Biochem. 31:375-385.

32. Mercier, J., and Manker, D. C. 2005. Biocontrol of soil-borne diseases and plant growth enhancement in greenhouse soilless mix by the volatileproducing fungus Muscodor albus. Crop Prot. 24:355-362.

33. Mondal, S. N., and Hyakumachi, M. 1998. Carbon loss and germinability, viability, and virulence of chlamydospores of Fusarium solani f. sp. phaseoli after exposure to soil at different $\mathrm{pH}$ levels, temperatures, and matric potentials. Phytopathology 88:148-155.

34. Nantawanit, N., Chanchaichaovivat, A., Panijpan, B., and Ruenwongsa, P. 2010. Induction of defense response against Colletotrichum capsici in chili fruit by the yeast Pichia guilliermondii strain R13. Biol. Control $52: 145-152$

35. Neher, O. T., Johnston, M. R., Zidack, N. K., and Jacobsen, B. J. 2009. Evaluation of Bacillus mycoides isolate BmJ and B. mojavensis isolate 203-7 for the control of anthracnose of cucurbits caused by Glomerella cingulata var. orbiculare. Biol. Control 48:140-146.

36. Niranjan Raj, S., Chaluvaraju, G., Amruthesh, K. N., Shetty, H. S., Reddy, M. S., and Kloepper, J. W. 2003. Induction of growth promotion and resistance against downy mildew on pearl millet (Pennisetum glaucum) by rhizobacteria. Plant Dis. 87:380-384.

37. Orhan, E., Esitken, A., Ercisli, S., Turan, M., and Sahin, F. 2006. Effects of plant growth promoting rhizobacteria (PGPR) on yield, growth and nutrient contents in organically growing raspberry. Sci. Hortic. 111:38-43.

38. Park, K. S., and Kim, C. H. 1992. Identification, distribution and etiological characteristics of anthracnose fungi of red pepper in Korea. Korean J. Plant Pathol. 8:61-69.

39. Patharakorn, T., Arpornsuwan, T., Wetprasit, N., Promboon, A., and Ratanapo, S. 2010. Antibacterial activity and cytotoxicity of the leaf essential oil of Morus rotunbiloba Koidz. J. Med. Plants Res. 4:837-843.

40. Peres, N. A., Timmer, L. W., Adaskaveg, J. E., and Correll, J. C. 2005. Lifestyles of Colletotrichum acutatum. Plant Dis. 89:784-796.

41. Pretel, M. T., Serrano, M., Amoros, A., Riquelme, F., and Romojaro, F. 1995. Non-involvement of ACC and ACC oxidase activity in pepper fruit ripening. Postharvest Biol. Technol. 5:295-302.

42. Ramamoorthy, V., Viswanathan, R., Raguchander, T., Prakasam, V., and Samiyappan, R. 2001. Induction of systemic resistance by plant growth promoting rhizobacteria in crop plants against pests and diseases. Crop Prot. 20:1-11.

43. Rickard, D. A. 2000. Review of phosphorus acid and its salts as fertilizer materials. J. Plant Nutr. 23:161-180.

44. Romero, D., Pérez-García, A., Rivera, M. E., Cazorla, F. M., and de Vicente, A. 2004. Isolation and evaluation of antagonistic bacteria towards the cucurbit powdery mildew fungus Podosphaera fusca. Appl. Microbiol. Biotechnol. 64:263-269.

45. Romine, M., and Baker, R. 1973. Soil fungistasis: evidence for an inhibitory factor. Phytopathology 63:756-759.

46. Ryu, C.-M., Farag, M. A., Hu, C.-H., Reddy, M. S., Kloepper, J. W., and Parě, P. W. 2004. Bacterial volatiles induce systemic resistance in Arabidopsis. Plant Physiol. 134:1017-1026.

47. Ryu, C.-M., Farag, M. A., Hu, C.-H., Reddy, M. S., Wei, H.-X., Paré, P. W., and Kloepper, J. W. 2003. Bacterial volatiles promote growth in Arabidopsis. Proc. Natl. Acad. Sci. USA 100:4927-4932. 
48. Sang, M. K. 2010. Biological control of Phytophthora blight and anthracnose of pepper by antagonistic rhizobacteria and compost water extracts. Ph.D. dissertation, Korea University, Seoul, Republic of Korea.

49. Sang, M. K., Chun, S.-C., and Kim, K. D. 2008. Biological control of Phytophthora blight of pepper by antagonistic rhizobacteria selected from a sequential screening procedure. Biol. Control 46:424-433.

50. Sang, M. K., Kim, J.-G., and Kim, K. D. 2010. Biocontrol activity and induction of systemic resistance in pepper by compost water extracts against Phytophthora capsici. Phytopathology 100:774-783.

51. Sang, M. K., Oh, J. Y., and Kim, K. D. 2007. Root-dipping application of antagonistic rhizobacteria for the control of Phytophthora blight of pepper under field conditions. Plant Pathol. J. 23:109-112.

52. Sid, A., Ezziyyani, M., Egea-Gilabert, C., and Candela, M. E. 2003/4. Selecting bacterial strains for use in the biocontrol of diseases caused by Phytophthora capsici and Alternaria alternata in sweet pepper plants. Biol. Plant. 47:569-574.

53. Sid Ahmed, A., Ezziyyani, M., Pérez Sánchez, C., and Candela, M. E. 2003. Effect of chitin on biological control activity of Bacillus spp. and Trichoderma harzianum against root rot disease in pepper (Capsicum annuит) plants. Eur. J. Plant Pathol. 109:633-637.

54. Tayung, K., Barik, B. P., and Jha, D. K. 2010. Antifungal activity and biocontrol potential of metabolite produced by an endophytic Fusarium (MTCC-9622) against some postharvest pathogens. J. Agric. Technol. 6:409-419.

55. Wei, G., Kloepper, J. W., and Tuzun, S. 1996. Induced systemic resistance to cucumber diseases and increased plant growth by plant growth-promoting rhizobacteria under field conditions. Phytopathology 86:221-224.

56. Williamson, S. M., Guzmam, M., Marin, D. H., Anas, O., Jin, X., and Sutton, T. B. 2008. Evaluation of Pseudomonas syringae strain ESC-11 for biocontrol of crown rot and anthracnose banana. Biol. Control 46:279286.

57. Yoon, M.-A., Jeong, T.-S., Park, D.-S., Xu, M.-Z., Oh, H.-W., Song, K.B., Lee, W. S., and Park, H.-Y., 2006. Antioxidant effects of quinoline alkaloids and 2,4-di-tert-butylphenol isolated from Scolopendra subspinipes. Biol. Pharm. Bull. 29:735-739.

58. Zhang, S., White, T. L., Martinez, M. C., McInroy, J. A., Kloepper, J. W., and Klassen, W. 2010. Evaluation of plant growth-promoting rhizobacteria for control of Phytophthora blight on squash under greenhouse conditions. Biol. Control 53:129-135.

59. Zou, C.-S., Mo, M.-H., Gu, Y.-Q., Zhou, J.-P., and Zhang, K.-Q. 2007. Possible contributions of volatile-producing bacteria to soil fungistasis. Soil Biol. Biochem. 39:2371-2379. 